\title{
GuĐrún Steinpórsdóttir
}

\section{„minnið er gatasigti“ \\ Um minni og tráma í Stóra skjálfta eftir Auði Jónsdóttur}

Við erum hugarburður í frjálsu falli [...] við keppumst við að skrá niður augnablikin, segja hvert öðru sögur, festa fingur á mannkynssöguna meðan alheimurinn penst út allt par til hann nær endamörkum sínum. Við segjum allar pessar sögur af öllu pví sem á að hafa gerst eins og okkur finnst við muna pað hvert og eitt eftir sínu nefi. En í hvert skipti sem við segjum sögu tekur hún á sig nýja mynd og verður að nýrri sögu og að pessu leyti erum við og öll okkar tilvera dæmd til að vera skáldskapur. ${ }^{1}$

Á pessa leið komst rithöfundurinn Auður Jónsdóttir að orði í fyrirlestri sem hún hélt um heilann á fræðslufundi hjá Íslenskri erfðagreiningu. Minnið hefur verið Auði hugleikið bæði í skrifum og fyrirlestrum en pað er eitt meginviðfangsefni hennar í skáldsögunni Stóra skjálfta sem kom út árið 2015.2 Par segir frá persónunni Sögu sem í upphafi bókar fær prjú stór krampaflog en afleiðingar pess felast meðal annars í umfangsmiklu minnisleysi. ${ }^{3}$ Hennar

1 Auður Jónsdóttir, „Auður Jónsdóttir. Um heilann, opinn fræðslufundur um heilann í blíðu og stríðu“, Ílensk erffagreining, 12. desember 2015, fyrirlesturinn er aðgengilegur á netinu: https://vimeo.com/148931471.

2 Sjá til dæmis sama heimild og Auður Jónsdóttir, „Við erum stöðugt að skálda lífið“, Tímarit Máls og menningar 80: 1/2019, bls. 112-116.

3 Auður hefur áđur skrifað um flogaveikar persónur í bókunum Stjórnlaus lukka (1998), Vetrarsól (2008) og Ósjálfrátt (2012). Hún er sjálf flogaveik en í viðtali við Árna Matthíasson segist hún hafa byggt á eigin reynslu í skrifum á Stóra skjálfta til að veita verkinu trúverðugleika en sagan sé engu að síður skáldskapur enda

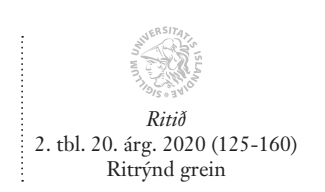

ㄷ 2020 Ritið, tímarit Hugvísindastofnunar og höfundur greinarinnar

Útgefandi:

Hugvísindastofnun Háskóla Íslands, Sæmundargötu 2, 102 Reykjavík
Birtist á vefnum http://www.ritid.hi.is. Tengiliður: ritið@hi.is

DOI: 10.33112 /ritid.20.2.6

Birt samkvæmt skilmálum Creative Commons BY (4.0). 
bíður pví pað erfiða verkefni að reyna að endurgera fortíðina og líf sitt til að skapa að nýju sína eigin lífsSögu. Pá parf hún að takast á við gömul áföll og henda reiður á tilfinningum peim tengdum en pað reynist prautin pyngri pegar minnið er eins gloppótt og raun ber vitni.

Stóri skjálfti fellur vel að rannsóknarsviði læknahugvísinda (e. medical bumanities) en innan peirrar fræðigreinar hefur skáldskapur meðal annars verið rannsakaður í peim tilgangi að skilja betur reynslu sjúklinga, tilfinningar peirra og aðstæður. ${ }^{4}$ Í pessari grein verður unnið í anda læknahugvísinda pví með hliðsjón af Stóra skjálfta verður fjallað um upplifun og reynslu aðalpersónunnar Sögu með tilliti til veikinda hennar. Fyrst verður skoðað hvernig flogaveiki er lýst í sögunni, hvaða líkingar eru jafnan hafðar um flog og hver áhrif peirra geta verið. Í kjölfarið verður kannað hvaða áhrif flogaveikin hefur á minni Sögu og skoðað hvaða aðferðum hún beitir til að rifja upp hið liðna. Í pví sambandi verður gaumur gefinn að pví hvernig frásögnin markar líf fólks og hvernig minnið er alltaf einum præði skáldskapur. ${ }^{5}$ Í ljósi

aðalpersónan afar ólík henni sjálfri. Árni Matthíasson, „Heilinn er tækifærissinnuð vinnslustöð“, Morgunblaðið, 29. nóvember 2015, bls. 48.

4 Læknahugvísindi eru meðal annars sprottin upp af pörf læknanema til að læra um samskipti við sjúklinga en pau eru víða kennd í læknisfræði. Á Íslandi hafa læknahugvísindi og undirgrein hennar frásagnarlæknisfræði (e. narrative medicine) verið kennd í læknadeild Háskóla Íslands í tæpan áratug en læknirinn Bryndís Benediktsdóttir og bókmenntafræðingarnir Ásdís Egilsdóttir og Dagný Kristjánsdóttir eru brautryðjendur í pví starfi. Samanber „Læknis- og bókmenntafræði hönd í hönd“, Háskóli Íslands, sótt 25. júlí 2020 af https://www. hi.is/fjarsjodur_framtidar5/laeknis_og_bokmenntafraedi_hond_i_hond. Peir sem aðhyllast læknahugvísindi telja mikilvægt að skoða sjúklinginn heildrænt; sem sagt huga jafnt að lífssögu hans og sjúkrasögu. Læknahugvísindi eru pverfagleg en pau sækja bæði til líf- og hugvísinda til að skoða og skilja betur pætti sem snúa að sjúklingum og heilbrigðisstarfsmönnum; til dæmis veikindi, sársauka, lækningar, samlíðan, frásagnir og samskipti; með pað að leiðarljósi að skilja manneskjuna betur og auka eigin félagslega færni. Раð er rökrétt að peir sem stunda læknahugvísindi sæki í skáldaða texta um sjúklinga, lækna og veikindi pví par er hægt að lesa um tilbúin samskipti, tilfinningalíðan fólks og upplifun sem jafnan er ekki lögð áhersla á í fræðilegum skrifum um sama efni innan læknisfræðinnar. Sjá til dæmis Anne Hunsaker Hawkins og Marilyn Chandler McEntyre, „Introduction. Teaching Literature and Medicine. A Retrospective and a Rationale“, Teaching Literature and Medicine, ritstjórar Anne Hunsaker Hawkins og Marilyn Chandler McEntyre, New York: The Modern Language Association, 2000, bls. 1-25, hér bls. 4-7.

5 Minni persóna og minni raunverulegs fólks er auðvitað ekki pað sama pví minni persóna er alltaf tilbúningur höfundarins. Til pess að hægt sé að skoða og greina minnið og minnisleysið í skáldsögu Auðar verða persónur hennar skoðaðar sem mannlíki. Mannlíki er heitið á persónum sem lesendur upplifa sem raunverulegar en ekki fyrst og fremst sem orðá blaði. Pegar persónur eru skoðaðar sem mannlíki eru 
pess að áföll úr fortíð Sögu leika stórt hlutverk í verkinu verður sérstaklega rætt um tengsl minnis og áfalla og dregið fram hvernig minningar um erfiða reynslu eru gjarnan ólíkar öðrum minningum. Stóri skjálfti er sumpart eins og leiðbeiningabók um minnið og óáreiðanleika pess. Í greiningu á verkinu verður pví jafnframt hugað að minni annarra persóna en Sögu og með hliðsjón af peim rætt um falskar minningar og hvernig einstaklingar kunna að minnast sömu atburða fortíðarinnar á ólíkan máta.

\section{Flog er einsog ...}

Hvað heitirðu?

Ókunnug augu stara á mig.

Heiti? Heiti ... hvað?

Hvað heitirðu? endurtekur röddin.

Hver heitir?

Pú, segir röddin. Pú heitir eitthvað. Manstu hver pú ert? Ég?

Á pessa leið hljómar fyrsti kafli skáldsögunnar Stóra skjálfta. Lesendum er hér fleygt inn í aðstæðurnar - in medias res - og kunna fyrir vikið að verða jafn ringlaðir og aðalpersóna verksins sem virðist ekki vita hvað hefur gerst, hvar hún er og jafnvel hver hún er. Fyrsti kafli sögunnar ber nafnið „Eftir skjálftann“ en kaflaheitið og titill bókarinnar ýta undir að lesendur geri ráð fyrir að jarðskjálfti hafi átt sér stað og að í fyrsta kaflanum sé aðalpersónan að reyna að fóta sig eftir pá reynslu. Fljótlega kemur pó í ljós að ekki er um náttúrufyrirbærið að ræða heldur skjálfta innra með ákveðinni persónu; nánar tiltekið hefur aðalpersónan fengið krampaflog. Pegar hún áttar sig á að priggja ára sonur hennar hefur týnst í miðju flogakastinu fær hún tvö stór flog til viðbótar.

peim gefnir mannlegir eiginleikar - par með talið minni - og pví er unnt að skoða pær og greina með hliðsjón af kenningum sálfræðinnar. Hugtakið mannlíki er fengið frá Bergljótu Soffíu Kristjánsdóttur sem notar bað fyrst í greininni „„Ómstríður taktur kvikra strengja“. Um Hin hálu prep Bjarna Bernharðs og sitthvað sem peim tengist“, Ritið 1/2016, bls. 107-134, hér bls. 125. Frásagnarfræðingurinn Uri Margolin var fyrstur til að benda á að menn upplifi sögupersónur sem fólk en hann talar pá um persónur eins og í pykjustuleikjum. Sjá Uri Margolin, „The What, the When, and the How a Being a Character in Literary Narrative“, Style 24/1990, bls. 453-468, hér bls. 455.

6 Auður Jónsdóttir, Stóri skjálfti, Reykjavík: Mál og menning, 2015, bls. 5. Eftirleiðis verður vísað til sögunnar með blaðsíðutali einu í sviga. 
Lesendur eru reyndar dregnir á upplýsingum um hvað hefur nákvæmlega hent aðalpersónuna sem er nafnlaus par til í priðja kafla en pá kemur í ljós að hún heitir Saga. Ýmsar vísbendingar eru pó gefnar í fyrstu premur köflunum um að hún hafi fengið flog en staðfestingin á pví kemur einnig undir lok priðja kafla. Nafnleysið er ein af vísbendingunum pví pað tengist minnis-

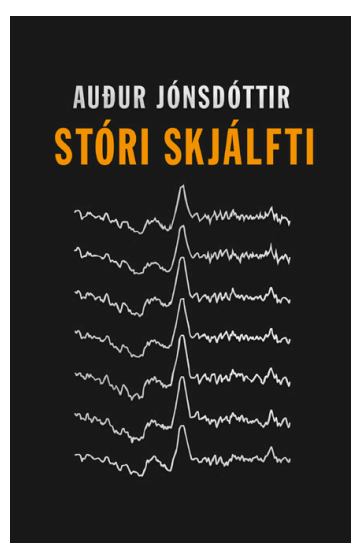
leysi Sögu sem er margoft spurð hvort hún muni hvað hafi gerst og hver hún sé. Pá er líkamlegri vanlíðan hennar lýst í paula; samanber að hún er illa áttuð, á erfitt með að tala, parf að sofa, svimar, riðar, er orkulaus og hefur höfuðverk. ${ }^{7}$ Auk pess kemur í ljós að hún hefur „migið á [sig] í krampanum“ (8). Allt eru petta dæmigerð einkenni krampaflogs eða grand mal flogs en í slíku flogi „verður allur heilinn fyrir truflun, viðkomandi missir samstundis meðvitund og fellur til jarðar. [...] Líkaminn stífnar í stutta stund og síðan fara kippir um líkamann. [...] Kippirnir ganga yfirleitt yfir og flogið tekur enda innan nokkurra mínútna. Á meðan viðkomandi er að komast til meðvitundar getur hann verið ruglaður og syfjaður en margir eru færir um að taka aftur upp práðinn par sem frá var horfið eftir að hafa hvílt sig smá stund."

Eins og sést á skilgreiningunni er krampaflog og reynslan af pví ekki ósvipuð lýsingu á jarðskjálfta og upplifun fólks af slíkum hamförum en bæði fyrirbæri eru óutreiknanleg og geta kallað fram tilfinningar á borð við ótta, hjálpar- og stjórnleysi. Raunar er reynslan af pessu tvennu svo ápekk að flogaveikir hafa beinlínis greint frá pví að peir hafi haldið að peir væru að fá flog í upphafi stórra jarðskjálfta. ${ }^{9}$ Pótt pað liggi beint við að líkja flogaveiki við jarðskjálfta skal tekið fram að pað er hvorki Saga, aðalpersóna Stóra

Sama heimild bls. 5-8.

8 „Spurningar og svör“, Lauf, sótt 25. júlí 2020 af http://www.lauf.is/ spurningar-and-svor/.

9 Skömmu eftir síðustu aldamót var gerð rannsókn í Seattle meðal flogaveikra og peirra sem fá flog ótengt flogaveiki. Pátttakendur voru spurðir um upplifun sína af stórum jarðskjálfta (6,8 á Richter) sem gekk yfir borgina pann 28. febrúar 2001. Einungis peir sem voru flogaveikir voru líklegri til að hafa haldið að peir væru að fá flog pegar skjálftinn hófst. Nathaniel F. Watson, Michael J. Doherty, Carl B. Dodrill, Don Farrell og John W. Miller, „The Experience of Earthquakes by Patients with Epileptic and Psychogenic Nonepileptic Seizures“, Epilepsia 43: 3/2002, bls. $317-$ 320, hér bls. 317. 
skjálfta, sem hefur jarðskjálftalíkingar um sjálfa sig og reynslu sína né aðrar persónur. Slíkar líkingar eru settar í brennidepil í sögunni til dæmis með pví að láta pær koma fram í fyrsta kaflaheitinu („Eftir skjálftann“), bókatitli og á kápumynd verksins sem sýnir heilalínurit sem einnig mætti túlka sem jarðskjálftalínurit. ${ }^{10}$ Pessar hugtakslíkingar ${ }^{11}$ eru ekki eingöngu vísbendingar um veikindi Sögu heldur eru pær jafnframt aðferð til að draga lesendur kannski ekki síst pá sem ekki hafa reynslu af flogum - inn í söguheiminn og liðka fyrir samsömun peirra með aðalpersónunni og auðvelda peim að skilja og finna pað sem hún finnur. ${ }^{12}$

Líkingar eru taldar skipta meginmáli til að öðlast skilning annarra pegar kemur að pví að lýsa veikindum fólks, sársauka og pjáningu einkum vegna pess hve einstaklingsbundin slík reynsla er. ${ }^{13}$ Hugtakslíkingar sem floga-

10 Í greininni „Hvorki stjórna né vera stjórnað“ bendir Auður Aðalsteinsdóttir á að titill bókarinnar vísi „í hið líkamlega ástand að vera í (grand-mal) flogi en einnig til jarðskjálfta“. Auk pess nefnir hún að Suðurlandsskjálftinn sem átti sér stað um síðustu aldamót hefur verið kallaður Stóri Suðurlandsskjálftinn. Auður Aðalsteinsdóttir, „Hvorki stjórna né vera stjórnað“, Andvari 141/2016, bls. 87-97, hér bls. 92.

11 Hér er horft til kenninga Georges Lakoffs og Marks Johnsons um hugtakslíkingar. Í bókinni Metaphors We Live By segja peir líkingu vera aðferð til að skilja eitt fyrirbæri í ljósi annars. Samkvæmt peim einkenna tvö hugtakssvið (e. conceptual domains) hverja líkingu en hluta af einu sviði, upptakasviðinu (e. source domain), er varpað yfir á annað ólíkt, marksviðið (e. target domain), til að auka skilning á pví. Lakoff og Johnson segja að í hugum manna séu eins konar yfirskipaðar líkingar, hugtakslíkingar (e. metaphorical concepts) sem ákvarða hugsun peirra og mál á kerfisbundinn hátt en peir telja að allur skilningur mannsins og fullyrðingar hans byggist á líkingahugsun. Hugtakslíkingar eru ekki líkingar í hefðbundnum skilningi heldur óhlutbundin fyrirbæri sem stjórna að hluta hvernig hugtak er notað. Til að útskýra mál sitt frekar benda peir félagar á að margar líkingar í máli vitni um hugtakslíkinguna DEILUR ERU STRÍĐ; til dæmis: „hann reyndi að koma böggi á hana í sjónvarpsumræðunum en henni tókst vel að verja sig“; „skoðanir pínar eru óverjanlegar", „rök hans voru skotin i kaf af andstæðingum“. George Lakoff og Mark Johnson, Metaphors We Live By, Chicago: Chicago Press, 2003, fyrsta útgáfa 1980, bls. 3-6.

12 Fleiri atriði kunna auðvitað að skipta máli fyrir tilflutning (e. transportation) lesenda inn í söguheim Stóra skjálfta og samsömun með Sögu. Til dæmis getur pað hjálpað að sagan er fyrstu persónu frásögn en oft eiga lesendur auðveldara með að samsama sig aðalpersónum slíkra frásagna. Samanber Suzanne Keen, Empathy and the Novel, Oxford: Oxford University Press, 2007, bls. 96. Pá skiptir einnig máli að sagan hefst á pví að aðalpersónan er í vanda stödd en erfiðleikar persóna kalla frekast á samúð (e. sympatby) lesenda sem getur síðan próast í samlíðan (e. empathy) eftir pví sem peir kynnast persónunni nánar. Keith Oatley, The Passionate Muse. Exploring Emotion in Stories, New York: Oxford University Press, 2012, bls. 31.

13 Stephen Loftus, „Pain and its Metaphors. A Diological Approach“, Fournal of Medical Humanities 32: 15/2017, bls. 213-230, hér bls. 215. 
veikir hafa um reynslu sína af flogum eru afar margvíslegar og persónubundnar eins og á einatt við um líkinganotkun allra sjúklinga. Samkvæmt rannsókn Leendert Plug, Basil Sharrack og Markus Reuber eru pó prjár gerðir hugtakslíkinga hvað algengastar pegar flogaveikir ræða veikindi sín; раð еr að segja:

1. FLOGIĐ ER ORSAKAVALDUR/KRAFTUR (e. THE SEIZURE IS AN AGENT/FORCE)

2. FLOGIĐ ER ATBURĐUR/AĐSTÆĐUR (e. THE SEIZURE IS AN EVENT/SITUATION)

3. FLOGIĐ ER STAĐUR/RÝMI (e. THE SEIZURE IS A PLACE/SPACE). ${ }^{14}$

Að líkja flogi við jarðskjálfta fellur undir fyrstu gerðina, sem Plug, Sharrack og Reuber nefna, en dæmi um bað í máli er: ,jarðskjálfti er eins og kraftur sem tekur yfir líkama sjúklingsins'. Með pessari líkingu er oft notuð önnur líkingin sem peir félagar telja upp pví hún felur í sér að flogið sé atburður sem hefur upphaf og endi rétt eins og jarðskjálftar; samanber pegar krampinn bófst var hún ekki viðræðuhæf en pegar honum lauk var hún fljót að jafna sig. ${ }^{15}$ Samspil af pessu tagi kemur vel fram í líkinganotkun Sögu pegar hún ræðir flogaveiki sína. Hún hugsar gjarnan um hvert flog sem stakan atburð en líkir flogunum að vísu hvorki við kraft né jarðskjálfta ${ }^{16}$ heldur orsakavald, nánar tiltekið árásarmann sem getur ráðist á hana hvenær sem er og hvar sem er:

Í grúski í tölvunni minnist hún [Saga] unglingsstelpunnar sem hún var: Hún var ekki eins mikið frík pegar hún taldi sér trú um að hún sjálf réði ferðinni. Pegar hún hagaði sér eins og læknisfræðilega skilgreiningin á henni sjálfri væri bara djöfuls vitleysa fannst henni hún vera laus undan árásarmanninum sem elti hana eins og skugg-

14 Leendert Plug, Basil Sharrack og Markus Reuber, „Seizure metaphors differ in patients' accounts of epileptic and psychogenic nonepileptic seizures“, Epilepsia 50: 5/2009, bls. 994-1000, hér bls. 997.

15 Dæmi um priðju líkinguna; FLOGIĐ ER STAĐUR/RÝMI er til dæmis: Hann talar við mig á meðan ég er $i$ flogakastinu vegna pess að hann heldur að pá nái hann mér fyrr úr bví en ella. Sama heimild, bls. 997.

16 Persónur verksins ræða aðeins einu sinni um tengsl floga og jarðskjálfta sín á milli. Pað er pegar Lilja Dögg og Óðinn - unglingar sem hjálpa Sögu - segja henni frá grein par sem kemur fram að: „Bandarískir vísindamenn segjast hafa fundið leið til að nota sömu tækni til að spá fyrir um flog flogaveikisjúklinga og notuð er til að spá fyrir um hvenær jarðskjálfti muni eiga sér stað.“ (242) 
inn. Honum sem henti sér á hana pegar síst skyldi. Fleygði henni kylliflatri á jörðina, hvar sem var, hvenær sem var; meðvitundarlausri meðan hann nauðgaði henni svo hún froðufelldi og meig eða skeit á sig, engdist um í fýlunni af sjálfri sér.

Hún práði að ná stjórninni, ráða eigin líkama, eigin lífi; stjórna öllu gangverki heimsins ef pess pyrfti með. (178-179)

Líkinganotkun Sögu dregur vel fram óttann og valdaleysið sem hún finnur fyrir vegna floganna. Hún práir að vera við stjórnvölinn og ráða yfir eigin líkama en í sögunni kemur fram að sem unglingur hafi hún logið að lækninum sínum að hún drykki ekki áfengi til að hann stækkaði lyfjaskammtinn hennar „eftir hvern krampa sem hafði brotist út eftir næturlangt sukk“ (179). Með pví að stjórna eigin lyfjagjöf telur Saga sér trú um að hún hafi valdið en ekki árásarmaðurinn. Staðreyndin er pó sú að hún er aldrei óhult; flogin gera ekki boð á undan sér svo hræðslan við ógnina er stöðug.

Í orðræðu um veikindi og sársauka er pekkt að fólk nýti sér árásarmyndmál pví pað talar gjarnan um sjúkdóma og veikindi sem orrustu eða stríð par sem sjúklingar berjast upp á líf og dauða. Í ljósi pess er til dæmis hugsað um lækna sem herstjóra, tækni sem vopn og líkama sjúklings sem orrustuvöll. Með slíkum líkingum er lögð áhersla á alvarleika veikindanna og sársaukans um leið og pær fela í sér hræðsluna og skelfinguna sem sjúklingar upplifa gjarnan. ${ }^{17}$ Pótt árásarmyndmál sé í brennidepli í lýsingum Sögu á reynslu sinni af flogaköstum hér að framan er pað að sínu leyti óhefðbundið pví tengingar við stríð og hermennsku eru ekki augljósar par sem árásarmaðurinn er nauðgari. ${ }^{18}$ Líkinganotkun Sögu kann að markast af samfélagslegum áhrifum sem líklegt er að höfundur bókarinnar hafi orðið fyrir. ${ }^{19}$ Á Íslandi eru stríð blessunarlega ekki daglegur veruleiki en meira máli skiptir að hér er kvenkyns persóna sem talar en kynferðislegar árásir á konur hafa verið meiri en á karlana. ${ }^{20}$ Eins og lýsing Sögu vitnar um er upplifun hennar af

17 Stephen Loftus, „Pain and its Metaphors. A Dialogical Approach“, bls. 217; Bergljót Soffía Kristjánsdóttir og Guðrún Steinpórsdóttir, „„Hvað var sett í kássuna?“ eða um blöndun, líkingar og fleira“, Leknablaðið 102/2016, bls. 358-361.

18 Í stríðum er nauðganir algengar og pví gjarnan stór páttur í upplifun kvenna af peim. Alla jafna fer pó lítið fyrir nauðgunarlíkingum í umræðu um veikindi og reynslu af peim en meiri áhersla er lögð á líkingar sem snúa að hernaði, vopnum og umráði yfir landssvæði.

19 Sjá umfjöllun George Lakoff og Mark Johnson um samfélagslega markaðar líkingar; George Lakoff og Mark Johnson, Metaphors We Live By, bls. 4-5.

20 Stóri skjálfti gerist í Reykjavík í nútímanum. Par sem söguheiminum svipar mjög til peirrar Reykjavíkur sem við pekkjum úr hinum raunverulega heimi er hér 
flogum í takt við reynslu brotapola nauðgana sem sviptir eru valdi yfir eigin líkama og finna einatt til ótta og óöryggis í kjölfar ofbeldisins. ${ }^{21}$ Í ljósi pess hve tíðir kynferðisglæpir eru og að umræða um pá, pekking og skilningur hefur aukist til muna síðustu áratugi er líklegt að fleiri lesendur - kannski ekki síst konur ${ }^{22}$ - tengi við líkingar Sögu en ef jarðskjálftalíkingar hefou verið í forgrunni í lýsingum hennar. ${ }^{23}$

Sársaukinn og pjáningin sem veikindin valda Sögu verða enn skýrari pegar hún greinir frá pví að árásarmaðurinn er ekki utanaðkomandi aðili heldur býr hann innra með henni:

gert ráð fyrir að samfélagsmyndin, til dæmis hvað varðar fjölda kynferðisafbrota, sé svipuð í báðum heimum. Í skýrslu sem Jafnréttisstofa tók saman kemur fram að konur voru í miklum meirihluta peirra sem leituðu til Neyðarmóttöku vegna nauðgunar á árunum 1993-2012. Fjöldi karla var 1-10 á ári en fjöldi kvenna 42-142. Frá árinu 2001 leituðu árlega yfir hundrað konur til Neyðarmóttökunnar. Tölulegar upplýsingar. Hlutfoll og fjöldi karla og kvenna á ýmsum sviðum samfélags, tekið saman af Jafnréttisstofu, október 2013, bls. 31. Ársskýrslur Stígamóta vitna um að konur leiti frekar bangað en karlar. Í skýrslunni frá árinu 2018 (sem er sú nýjasta á vefnum pegar petta er skrifað) kemur fram að pað ár hafi 311 konur (86,6\%) leitað aðstoðar en 47 karlar (13,1\%). Steinunn Gyðu- og Guðjónsdóttir (ritstjóri), Stígamót. Ársskýrsla 2018, Reykjavík: Stígamót, 2018, bls. 30. Anna Bentína Hermansen, starfsmaður Stígamóta, hefur bent á að kynferðisafbrot gegn körlum (og raunar öll kynferðisafbrot) eru vanskráð en að tíðnikannanir gefi vísbendingar um að brotið sé á fleiri konum en körlum. Sér til stuðnings vitnar hún í hlutföll karla og kvenna sem leita aðstoðar Stígamóta og í tíðnikönnun Hrefnu Ólafsdóttur félagsráðgjafa á umfangi kynferðisofbeldis á börnum. Könnun Hrefnu var sú fyrsta af pessu tagi sem var gerð hérlendis en hún var unnin á árunum 1999-2003. Anna Bentína Hermansen, „Karlmenn verða fyrir kynferðisafbroti“, Stígamót, sótt 6. júlí 2020 af https://www. stigamot.is/is/fraedsluefni/greinar/karlmenn-verda-fyrir-kynferdisofbeldi.

21 Sjá til dæmis Steinunn Gyðu- og Guðjónsdóttir (ritstjóri), Stígamót. Ársskýrsla 2018, bls. 44-45; Inbar Kremer, Israel Orbach og Tova Rosenbloom, „Body Image Among Victims of Sexual and Physical Abuse“, Violence and Victims 28: 2/2013, bls. 259-273, hér bls. 260-261. Ásdís Helga Óskarsdóttir hefur bent á að líkingin flogaveiki sem ókunnugur árásarmaður, í Stóra skjálfta, minni á skrif Svövu Jakobsdóttur í greininni „Reynsla og veruleiki“ en par fjallar Svava um ótta kvenna við ókunnuga karlmenn og líkamlega yfirburði peirra. Ásdís Helga Óskarsdóttir, „leiðin er innávið og uppímóti“. Um fjórðu bylgju femínismans og íslenskar kvennabókmenntir, MA-ritgerð í íslenskum bókmenntum við Háskóla Íslands, 2019, aðgengileg á vefnum Skemman: https:// skemman.is/bitstream/1946/32686/1/Meistararitgerd_AsdisHelgaOskarsdottir. pdf, bls. 8-9.

22 Nefnt skal að lesendur eiga gjarnan auðveldara með að samsama sig sögupersónunum af sama kyni og peir eru sjálfir. Keith Oatley, The Passionate Muse. Exploring Emotion in Stories, bls. 180.

23 Samanber Bergljót Soffía Kristjánsdóttir, Guðrún Steinpórsdóttir og Sigrún Margrét Guðmundsdóttir, „,,eins og að reyna að æpa í draumi“. Inngangur að pema“, Ritið 3/2018, bls. 1-15, hér bls. 10-12. 
Pað brakaði í beini, hann fleygði pér endilangri á jörðina og barnið pitt grét. Hann hristi pig svo froðan flæddi út á milli tannanna í pér, pú meigst á pig og drullan lak út úr pér, pú öskraðir eins og djöfullinn sem býr í iðrum okkar allra. Рað er hann sem ræður líkama pínum, hann á pig. Hann kemur aftan að pér pegar síst skyldi en parf aldrei að troða sér inn í pig pví hann býr innra með pér. Í líki pess sem pú treystir, sem pú neyðist til að treysta dag hvern til að geta lifað. (207)

Hér kemur fram að veikindi Sögu eru að sjálfsögðu hluti af líkama hennar en ekki ytra áreiti eins og fyrri lýsing gæti gefið til kynna. Saga hugsar um líkamann sem hús sem hún deilir með árásarmanninum. ${ }^{24}$ Par með leggur hún frekari áherslu á hættuna sem hún býr við pví lýsingin getur minnt lesendur á að flest kynferðisafbrot eru framin af einstaklingum sem brotaboli pekkir; jafnt vinum, kunningjum og fjölskyldumeðlimum; og að oft eiga pau sér stað innan veggja heimilisins; sem undir eðlilegum kringumstæðum ætti að vera öruggt. Vanmáttur Sögu kristallast í pverstæðunni sem einkennir samband hennar við eigin líkama; hún hefur ekki stjórn á honum og hræðist pað sem hann getur tekið upp á um leið og hann er forsenda pess að hún er til og getur lifað lífinu. Hugsanlega er ofbeldislíkingin afleiðing persónulegrar reynslu Sögu; pó ekki af kynferðislegu ofbeldi heldur af pví að hafa alist upp á heimili ofbeldismanns fyrstu ár lífs síns; að pví verður betur vikið hér á eftir.

Eins og fram hefur komið eru lyfin vopn Sögu gegn árásarmanninum/ flogaveikinni. ${ }^{25}$ Pegar hún verður ólétt ráðleggur læknir henni að hætta á lyfjunum pví bau geti haft alvarlegar aukaverkanir. Hún kýs að hunsa ráðin „pví hún vildi umfram allt ekki hugsa, allra síst muna eftir árásarmanninum. Hún vildi ekki hafa hann vomandi yfir sér á meðan hún væri með barn á brjósti. Hann passaði ekki inn í myndina af móður og barni“ (179). Saga telur sér trú um að hún hafi stjórn á líkamanum á meðgöngunni svo lengi sem hún heldur áfram á lyfjunum en pegar henni er gert að hætta inntöku peirra upplifir hún vanmátt og skelfingu: „Árásarmaðurinn gat komið hvenær sem er“ (179). Pótt veikindin marki sýn Sögu á eigin líkama er hún einnig með-

${ }_{24}$ Um líkinguna LÍKAMINN ER HÚS/BYGGING hafa ýmsir fjallað. Til dæmis George Lakoff, Jane Espenson og Alan Schwartz, Master Metaphor List, Second Draft, Berkeley: University of California, október 1991, fyrsta útgáfa ágúst 1989, bls. 192; Sigrún Margrét Guðmundsdóttir, „,Hann er bara á vondum stað“. Reimleikahús í kvikmyndinni Rökkri eftir Erling Óttar Thoroddsen“, Ritið 1/2019, bls. 101-136, hér bls. 122-123.

25 Auður Jónsdóttir, Stóri skjálfti, bls. 179. 
vituð um kosti hans pví pegar sonur hennar, Ívar, fæðist upplifir hún frelsi „undan árásarmanninum [og] [í] fyrsta skipti á ævinni [sér] hún líkama sinn sem vin, eða öllu heldur vinkonu“ (179). Breytt afstaða er að einhverju leyti aðferð Sögu til að afneita veikindunum og telja sér trú um að hún sé óhult og hafi stjórnina. En árásarmaðurinn er ekki langt undan pví pegar Saga fær stóru flogin prjú neyðist hún til að viðurkenna eigið stjórnleysi.

\section{„Bíddu, bvernig var petta allt saman?"}

Flogaköstin í upphafi Stóra skjálfta eru eins og öflugur jarðskjálfti pví í kjölfar peirra er minni Sögu í brotum. Hennar bíður pví pað flókna verkefni að reyna að setja saman fortíðina til að geta hent reiður á nútíðinni og hver hún eiginlega er. Helsti ótti Sögu er að fá ekki að hafa son sinn hjá sér vegna flogaveikinnar. Minnisvandræðin í kjölfar floganna auka óttann pví hún hræðist að vantraust fjölskyldunnar gagnvart sér komi til með að aukast átti bau sig á pví hve veik hún er.

Pegar Saga fær flogaköstin hefur hún ekki fengið krampakast í um tíu ár. Раð er afar einstaklingsbundið hvað kemur flogum af stað en meðal pess sem talið er auka hættu á flogakasti er álag, preyta og svefnleysi. ${ }^{26}$ Allt á við um Sögu sem hefur nýlega skilið við eiginmann $\operatorname{sinn}^{27}$ og á auk pess lítið, veikt barn. Pótt flogin séu aflvaki sögunnar eru pað afleiðingar peirra sem mestu máli skipta; pað er að segja minnisleysið og endurheimting minninga. ${ }^{28}$

${ }^{26}$ Nancy R. Temkin og Gay R. Davis, „Stress as a Risk Factor for Seizures Among Adults with Epilepsy“, Epilepsia 25: 4/1984, bls. 450-456. Pess ber að geta að mikil streita getur orsakað minnisleysi. Samanber Daniel L. Schacter, Seven Sins of Memory. How the Mind Forget and Remembers, Boston og New York: Houghton Mifflin Company, 2001, bls. 86-87.

27 Fyrrum eiginmaður Sögu heitir Bergur en í nafni hans felst ákveðinn merkingarauki sem undirstrikar hlutverk hans í sambandinu við Sögu. Nafnið Bergur „er leitt af sögninni að bjarga, $\rightarrow$ Berg-, og viðskeytinu -ur og merkir 'bjargvættur, hjálparhella'.“ Guðrún Kvaran og Sigurður Jónsson, „Bergur“, Nöfn Íslendinga, sótt 13. maí 2020 af snara.is. Bergur er með öðrum orðum kletturinn í lífi Sögu sá sem verndar hana gegn árásarmanninum en allan pann tíma sem pau voru saman fékk hún aldrei flogakast.

28 Flogaköstin má túlka sem líkingu fyrir „aðstæður pegar fólk hleypur á veggi og missir tökin“, eins og leikkonan og leikstjórinn Tinna Hrafnsdóttir hefur bent á. Slíkir árekstrar kalla oft á að fólk endurskoði sjálft sig og fortíðina en рað parf Saga svo sannarlega að gera pegar hún neyðist til að reyna að muna hið liðna og fara í gegnum erfiðar minningar til pess að skilja hver hún er. Sjá Júlía Margrét Einarsdóttir og Viðar Eggertsson, „,Pöggun er svo algeng í fjölskyldum“““, $R U ́ V$, 11. mars 2020, sótt 16. júní 2020 af https://www.ruv.is/frett/ thoggun-er-svo-algeng-i-fjolskyldum?fbclid=IwAR2iLLCpDt9qQ0OnevEhKo_ anwT9t8-ulxrSCfvOGJVFRqUvf6P5RH4nJGI. Tekið skal fram að Tinna hefur 
Einum præði minnir Stóri skjálfti á spennusögu pví Saga parf að setja sig í spor rannsakanda pegar hún les í ýmsar vísbendingar og ræðir við ólíka aðila til að reyna að rifja upp fortíðina. Pá parf hún einnig að gera upp við sig hvort minningarnar sem vakna hjá henni og sögur annarra af fortíðinni séu staðreyndir eða hugarburður. Fyrir vikið kallar sagan á að lesendur velti fyrir sér ólíkum hliðum minnisins og spyrji spurninga eins og: hvernig man fólk fortíðina, hvað velur pað að muna og hverju kýs pað að gleyma? Áður en fjallað verður um minni Sögu og hvaða aðferðir hún notar til að rifja upp hið liðna er rétt að fjalla stuttlega um minnið og endurheimtingu minninga.

Margir fræðimenn líta svo á að frásögnin sé grundvöllur mannlegrar hugsunar og gegni pess vegna margskonar hlutverkum eins og að liðka fyrir skilningi manna á sjálfum sér og öðrum sem og að efla og pjálfa ímyndunaraflið. ${ }^{29}$ Með frásögninni dregur fólk upp ákveðna mynd af sjálfu sér en sú mynd getur verið breytileg. ${ }^{30}$ I fyrirlestri sem Auður Jónsdóttir hélt um heilann benti hún einmitt á að hún gæti hæglega „skrifað skáldævisögu sína hundrað sinnum en samt nýja sögu í hvert skipti og atburðarásirnar ólíkar eftir pvi“'31 enda pyrftu atvikin sem fengju mest vægi ekki að vera pau hin sömu heldur gæti mat hennar á peim verið breytilegt eftir pví sem hún skrifaði „ævisögur“ sínar oftar. ${ }^{32}$ Pegar fólk segir sögur af sjálfu sér og öðrum reiðir pað sig á minnið. ${ }^{33}$ Minningar fólks eru auðvitað einstaklingsbundnar

lokið við að kvikmynda Stóra skjálfta en áætlað er að kvikmyndin verði frumsýnd 2021.

29 Sjá til dæmis Jerome Bruner, "The Narrative Construction of Reality“, Critical Inquiry 18: 1/1991, bls. 1-21, hér bls. 4; Daniel D. Hutto, „Narrative and understanding persons“, Royal Institute of Philosophy Supplements 60/2007, bls. 1-15, hér bls. 2.

30 Samanber Paul John Eakin, „What Are We Reading When We Read Autobiography?", Narrative 12: 2/2004, bls. 121-132.

31 Auður Jónsdóttir, „Auður Jónsdóttir. Um heilann, opinn fræðslufundur um heilann í blíðu og stríðu“, https://vimeo.com/148931471.

32 Sama heimild. Hérlendis er bókmenntafræðingurinn Gunnpórunn Guðmundsdóttir brautryðjandi í rannsóknum á minni, gleymsku og frásögnum. Sem dæmi um greinar hennar og bækur sem tilheyra pví rannsóknarsviði má nefna Gunnpórunn Guðmundsdóttir, Borderlines, Autobiography and Fiction in Postmodern Life Writing, Amsterdam: Rodopi, 2003; „Skáldað um líf. Sjálfsævisögur sem bókmenntagrein á tímum póstmódernisma“, Skírnir vor/2003, bls. 109-125; „Blekking og minni. Binjamin Wilkomirski og helfararfrásagnir“, Ritið 3/2006, bls. 39-51; „,Minnið er alltaf að störfum“. Mótun endurminninga og sjálfs í Minnisbók og Bernskubók Sigurðar Pálssonar“, Ritið 2/2013, bls. 135-148; „Frásögn án gleymsku og dauða. Sjálfstjáning á samfélagsmiðlum“, Ritið 3/2015, bls. 161-179; „„Allt sem pú gerir breytist í reynslu“. Ferðalag um sjálfsævisöguleg skrif Jóns Gnarr“, Tímarit Máls og menningar 1/2016, bls. 52-61 og Representations of Forgetting in Life Writing and Fiction, London: Palgrave Macmillan, 2016.

33 Мeð orðinu minni er hér átt við minningar sem fólk geymir í langtímaminninu. 
pví pótt tveir eða fleiri geti átt minningu af sama atburði eru sjónarhornin alltaf ólík og minningarnar par með aldrei nákvæmlega pær sömu. ${ }^{34}$ Pá er vert að hafa í huga að væntingar, áhugi, langanir og skoðanir okkar sem og annarra lita hvað við munum og hvernig. ${ }^{35}$

Öll reynsla sem maðurinn upplifir á ævinni markast sem slóðir í minni hans. Slóðirnar bera með sér allar pær tilfinningar sem menn hafa á peim tíma sem minningin varð til en eitt af hlutverkum heilans er að safna saman pessum slóðum og setja í samhengi við nýja reynslu mannsins. Á einn eða annan hátt tengist hver ný reynsla annarri úr fortíðinni sem skýrir til dæmis hvers vegna ákveðnar aðstæður eða atburður geta kallað fram minningu um aðrar aðstæður eða atburð. Heimsókn á tiltekinn stað getur til dæmis dregið fram minningar um staðinn pegar hann var heimsóttur síðast og sömuleiðis geta tilfinningar sem fólk bar til staðarins í fortíðinni vaknað upp aftur við endurkomu. ${ }^{36}$ Svipuð áhrif geta til dæmis lykt, bragð og tónlist haft á minningar einstaklings og tilfinningar.

Pegar fólk rifjar upp hvað hefur á daga pess drifið og ræðir minningar sínar er ekki endilega víst að frásögnin sé ávallt í réttri tímaröð. Sálfræðingurinn Daniel L. Schacter hefur líkt minningum fólks við flókinn vefnað

34 Um petta hefur Auður Jónsdóttir fjallað í viðtali við Árna Matthíasson en par segir hún: „Ég hef upplifað pað sem fullorðin að glíma við minningar sem ég var búin að gleyma en systir mín ekki. Рað kemur mér stundum gjörsamlega í opna skjöldu pegar systir mín, sem er fimm árum yngri en ég, man eitthvað sem ég man ekki en samt vorum við báðar viðstaddar. Petta er skrýtið en nokkuð sem margir hafa upplifað og við erum alltaf að upplifa. Ef við myndum tala um pessa stund par sem við sitjum núna eftir nokkur ár pá hefðum við upplifað hana hvort á sinn hátt. Svo er líka misjafnt hvað við festum í minninu og hvernig við gerum pað og misjafnt hvað hentar heilanum, hvernig hentar honum að hafa hlutina til að fúnkera áfram.“ Árni Matthíasson, „Heilinn er tækifærissinnuð vinnslustöð“, bls. 48.

35 Árni Kristjánsson, „Að skapa minningar. Minni athygli og áreiðanleiki vitnisburðar“, Sálfreðiritið 19/2014, bls. 21-39, hér bls. 21.

36 Patrick Colm Hogan, The Mind and its Stories. Narrative Universals and Human Emotion, Cambridge, New York, o.fl.: Cambridge University Press, 2003, bls. 156-159 og Daniel L. Schacter, Seven Sins of Memory. How the Mind Forget and Remembers, bls. 9. Rithöfundurinn Svava Jakobsdóttir lýsti upplifun af pessu tagi afar vel í viðtali sem Dagný Kristjánsdóttir tók við hana. Svava sagði: „Ég varð fyrir reynslu fyrir skömmu sem mér fannst mjög einkennileg. Ég var á ferð í Kanada, í bænum par sem ég ólst upp, og stóð á stígnum par sem ég var vön að ganga á leiðinni í skólann. Skyndilega var mér kippt út úr nútímanum og ég varð aftur barn. Ég var á sviði bernskunnar, í hinni sterku tilfinningalegu upplifun barnsins og ekkert annað var til. Pegar petta var afstaðið gerði ég mér grein fyrir að ég hafði orðið átta 
par sem fléttast saman minningar um sérstæða atburði og hversdagslegar endurminningar um ákveðin tímaskeið. Hann segir að pað sé algengt að fólk hugsi um minnið og minningar á pann hátt að ferlið við að kalla fram minningu sé svipað pví að horfa á kvikmynd. Með öðrum orðum sé mögulegt að spóla fram og tilbaka í gegnum minnið, stoppa á völdum stöðum og sjá ljóslifandi fyrir sér atburði fortíðarinnar allt fram til dagsins í dag. Samkvæmt Schacter er endurheimting minninga pó ekki svona einföld en hann heldur pví fram að minnisgeymsla (e. memory storage) mannsins sé afar brotakennd og slitrótt. Minningar sem menn hafi um liðna atburði séu einangraðar og brotakenndar og pví sé pað manninum eiginlegt að muna hluta af samtölum og sum andlit. Pá segir Schacter að minningar séu ekki aðeins brotakenndar heldur dofni pær með aldrinum svo pað sérstaka sem maðurinn man eins og ákveðið samtal eða gjörð gleymist en pað almenna situr eftir í minninu eins og til dæmis hvar einstaklingur hitti ákveðna manneskju og átti samtal við hana. Pegar menn rifja upp atburði taka peir pví brot úr fortíðinni og raða saman í heildarmynd svo í rauninni muna peir ekki fortíðina heldur búa peir hana til að nýju með pví að nýta ímyndunaraflið til að fylla inn í eyðurnar. Stundum er hið liðna mótað pannig að pað endurspeglar núverandi tilfinningar ekki síður en fyrri reynslu pess sem segir frá og stundum endurspeglar pað alls ekki pá reynslu sem einstaklingur hefur upplifað. Par með getur nútíðin mótað fortíðina og jafnvel skapað nýja minningu. ${ }^{37}$

Minnið er semsagt alltaf að einhverju leyti skáldskapur eins og svo marg-

eða níu ára á meðan petta stóð yfir. Pað var ekki lengi. Ég var með öðru fólki sem virtist ekki hafa tekið eftir neinu.“ Dagný Kristjánsdóttir, „Hvert einasta orð er mikilvægt. Viðtal við Svövu Jakobsdóttur“, Kona með spegil. Svava Fakobsdóttir og verk hennar, ritstjóri Ármann Jakobsson, Reykjavík: JPV útgáfa, 2005, bls. 30-43, hér bls. 38. Viðtalið birtist fyrst í priðja hefti Tímarits Máls og menningar 1990.

37 Daniel L. Schacter, Searching for Memory. The Brain, the Mind, and the Past, New York: BasicBooks, 1996, bls. 89-91; Daniel L. Schacter, Seven Sins of Memory. How the Mind Forget and Remembers, bls. 9 og Patrick Colm Hogan, The Mind and its Stories. Narrative Universals and Human Emotion, bls. 262. 
ir hafa fjallað um, ${ }^{38}$ Auður Jónsdóttir par á meðal. ${ }^{39}$ Hvað varðar eyður í minni Sögu er hún verr stödd en margir aðrir pví stórir hlutar úr fortíð hennar virðast hafa purrkast út við flogaköstin - alltént tímabundið. ${ }^{40}$ Slíkt er reyndar ekki óvenjulegt pví algengur fylgikvilli stórra floga eru vandræði með minnið. ${ }^{41}$ Saga á erfiðast með að muna rétt eftir flogin prjú en pá man hún til dæmis ekki ákveðin orð, hvað hún heitir, hvar hún vinnur, hvað sonur

38 Sjá til dæmis Daniel L. Schacter, Seven Sins of Memory. How the Mind Forget and Remembers; Keith Oatley, Such Stuff as Dreams. The Psychology of Fiction, Oxford: John Wiley \& Sons, 2011, bls. 58-60; Árni Kristjánsson, „Að skapa minningar“, bls. 21-39; Gunnpórunn Guðmundsdóttir, „Mótun endurminninga og sjálfs í Minnisbók og Bernskubók Sigurðar Pálssonar“, bls 135-148 og sama „„Allt sem pú gerir breytist í reynslu“. Ferðalag um sjálfsævisöguleg skrif Jóns Gnarr“, bls. 54. Við réttarhöld eru vitni einatt látin sverja pess eið að pau segi satt og rétt frá atvikum en út úr peim frasa hefur sálfræðingurinn og minnisfræðingurinn Elizabeth F. Loftus snúið á skemmtilegan hátt: „Do you promise to tell the truth, the whole truth or whatever it is you think you remember?“ Elizabeth F. Loftus, „Memory Faults and Fixes“, Issues in Science and Technology 18: 4/2002, bls. 41-50, hér bls. 41. Orð hennar vitna um hve minnið er brigðult. Nefnt skal að Loftus hefur áratuga reynslu af pví að gera rannsóknir sem hafa leitt í ljós hve mönnum er tamt að endurskapa fortíðina; yfirlit yfir slíkar rannsóknir má til dæmis sjá í Elizabeth F. Loftus og J. C. Palmer, „Eyewitness Testimony“, Introducing Psychological Research, ritstjórar Philip Banyard og Andrew Grayson, London: Palgrave, 1996, bls. 305-309 og Elizabeth F. Loftus, „Make-Believe Memories“, American Psychologist 58: 11/2003, bls. 867873. Um tengsl sjálfsævisagna og skáldskapar segir Gunnpórunn Guðmundsdóttir: „Sjálfsævisögur byggjast ekki aðeins á skáldskap á yfirborðinu heldur einnig í djúpgerð sinni. Рað er ekki par með sagt að úr verði skáldskapur, heldur að höfundar færi sér skáldskap í nyt. Skáldskap í sjálfsævisögum má finna í byggingu peirra, í pví hvernig er farið með minni, í sjálfssköpun, pegar skrifað er um aðra í sjálfsævisögum og í meðferð á heimildum, en öll pessu atriði eru einnig notuð sem tæki til pekkingar og sjálfssköpunar. Höfundar nota pessa pætti í eigin págu: til að skoða fortíðina eða til að mynda sjálf í sjálfsævisögu. Рað er aldrei hægt að fjarlægja alveg skáldskap úr sjálfsævisögum [...]. Gunnpórunn Guðmundsdóttir, „Skáldað um líf“, bls. 122-123.

39 Í hugvekju um minnið og skáldskapinn segir Auður: „Við erum jú eigin skáldskapur. Heilinn pikkar út pær minningar sem hann vill geyma eftir hentisemi; við ritskoðum ósjálfrátt atvik og orð, lögum upplifun okkar að hugarheimi okkar. Við erum stöðugt að skálda lífið. [...] Dæmd til að búa okkur sjálf til meðan heilinn sorterar veruleikann og lagar að pörfum persónuleikans, eftir pví hvernig pað hentar okkur að muna og tjá hann.“ Auður Jónsdóttir, „Við erum stöðugt að skálda lífið“, bls. 113.

40 Í umfjöllun um verkið bendir Már Másson Maack réttilega á að „Saga er nánast eins og autt blað í upphafi sögunnar vegna minnisleysisins.“ Már Másson Maack, „Lífið er ráogáta“, Bókmenntaborgin.is, desember 2015, sótt 24. apríl 2020 af https://bokmenntaborgin.is/umfjollun/stori-skjalfti. Í nafni Sögu felst sem sagt merkingarauki, hún parf að raða saman brotum úr fortíðinni til að skrifa sögu sína og skilja sjálfa sig.

41 „Spurningar og svör“, Lauf, sótt 25. júlí 2020 af http://lauf.is/spurningar-and-svor/. 
hennar er gamall og hvers vegna hún og barnsfaðir hennar eru skilin. Atburðir úr fortiððinni eru einnig í móðu. Erfiðleikar hennar snúa semsagt fyrst og fremst að meðvitaða minninu (e. explicit memory) sem fela í sér atriði eins og persónulegar minningar og staðreyndir um heiminn..$^{42}$ Minni Sögu kallast á við byggingu bókarinnar pví í upphafi eru kaflarnir stuttir enda er pá minnisleysið og óreiðan mest áberandi en eftir pví sem líður á söguna og minningar Sögu verða skýrari lengjast peir.

Saga beitir ýmsum aðferðum til að ná tökum á minninu. Fyrir pað fyrsta má nefna að hún reynir að fá upplýsingar um sjálfa sig með pví að lesa í svipbrigði sinna nánustu, útlit peirra og hreyfingar en ekki síst með pví að túlka ummæli peirra og athugasemdir sem beinast að henni. Hún líkir samvistum við fólkið sitt við „göngu um speglasal“ (174) pví „augu peirra sýna [henni hana] sjálfa“ (174). En hún er svo illa á sig komin að hún gerir sér ekki grein fyrir „hvort spegilmyndin sé skrumskæld eða ekki“ (174) enda ljóst að ólík samskipti kalla á ólík hlutverk einstaklingsins svo aðstandendur „sjá ekki öll sömu manneskjuna“ (174). ${ }^{43}$ Til dæmis les Saga hræðslu úr látæði móður sinnar en greinir ópol í sinn garð af hendi systur sinnar.

Lykt og hlutir eru meðal pess sem vekja upp gleymdar minningar hjá Sögu en í sumum tilvikum minnist hún atburða og fólks sem hún hefur ekki leitt hugann að í mörg ár. Ilmur af kjötsúpu minnir hana til dæmis á sögur sem pabbi hennar sagði henni og systkinum hennar pegar pau voru börn og hjálpuðu honum að elda slíka súpu. Minningin vekur bæði vellíðan hjá Sögu og færir henni öryggi; hún er staðfesting á að minnið er ekki alveg horfið, í kjölfarið rifjast enda upp fyrir henni ýmsar aðrar óvæntar minningar í engri sérstakri tímaröð. Раð kemur pó sîðar fram að minningin er ekki aljákvæð; ástæðan fyrir samvinnunni er sú að móðir Sögu hefur látið sig hverfa vegna vanlíðunar en pað man Saga ekki eða kýs að horfa framhjá pví.

Pótt minnið komi smátt og smátt til baka efast Saga sífellt um að minningar hennar séu réttar eins og kemur skýrt fram pegar hún reynir að rifja upp við hvað hún hefur starfað:

42 Magnús Jóhannsson, Pórunn Anna Karlsdóttir, Engilbert Sigurðsson, „Aftur til fortíðar. Sjúkratilfelli og yfirlit um afturvirkt minnisleysi“, Leknablaðið 97/2011, bls. 159-164, hér bls. 159.

43 Hér er vel undirstrikuð sú viðtekna skoðun að maðurinn hafi margar sjálfsmyndir, sjá til dæmis Sheldon Stryker, „Identity Theory and Personality Theory. Mutual Relevance“, Fournal of Personality 75: 6/2007, bls. 1083-1102, hér bls. 1088-1091 og Paul John Eakin, How Our Lives Become Stories. Making Selves, Ithaca og London: Cornell University Press, 1999. 
Ég hef alltaf unnið við stjórnun og skipulagningu í bíói, já, og eitthvað parna í leikhúsi, jú! Eða ... Er pað nokkuð hugarburður minn? Af hverju finnst mér að heilinn búi til minningar um atburði sem aldrei áttu sér stað? Bíddu, hvernig var betta allt saman? (76)

Eins og sést efast Saga um skynjun sína og skilning og veit ekki fyrir víst hvað er satt og rétt og hvað ekki. Líkingar sem hún hefur um eigið minni vitna einnig um efann sem hún finnur fyrir og að hún treystir ekki fullkomlega pví sem hún telur sig muna, samanber: „hann [Bergur] má ekki vita að minnið er gatasigti, pannig líður mér að minnsta kosti“ (28); „Mig verkjar í höfuðið af öllum pessum myndum, framandi og kunnuglegum í senn pegar pær steypast ofurskýrar yfir mig en örsnöggt eins og ég sé bilað sjónvarp“ (43); „Minnið í mér er álíka pottbétt og drukkinn stjórnmálamaður“ (145). Pá skal einnig nefnt að „annað sjálf [Sögu], fartölvan“ (117) er með vírus en skjal í henni sem „átti að heita dagbókin mín“ er bjagað en par hafa „stafirnir hl[aupið] í hrúgur eins og ringlaðir maurar“ (117). Ástandið á tölvunni rímar semsagt við ástandið á minni Sögu; pörf er á endurræsingu peirra beggja eins og ein sögupersónan kemst að orði. ${ }^{44}$

Minnisgloppurnar og líkingarnar um minni Sögu vitna um stjórnleysið sem hún finnur fyrir; pað er sumpart eins og hún sé aftengd raunveruleikanum pví hún man ekki fortíðina og getur bar með ekki skilið nútíðina til fulls. Pess utan er „eins og minnið sortéri minningarnar [hennar] í bærilegar og óbærilegar pegar [hún] reynir að púsla tilveru [sinni] saman.“ (82) „Óbægilegar hugsanir valda hræðilega vondum höfuðverk“ (82) en hún finnur „til líkamlegs sársauka við að beina huganum að ákveðnum hlutum“ (79) og er pví „fyrirmunað að rifja pá upp“ (79). Í fyrstu kemur sársaukinn einkum pegar Saga reynir að rifja upp erfiðleikana í sambandi hennar og Bergs og skilja hvers vegna hann flutti frá henni - en heillegustu minningar hennar af peim tveimur eru allar jákvæðar svo sambandsslitin eru henni óskiljanleg. ${ }^{45}$ Síðar verður ljóst að erfið veikindi sonar peirra - og áfall í æsku Sögu - eru líklega rót sambandserfiðleikanna og tengjast sársaukanum sem Saga finnur fyrir pegar hún reynir að muna hið óbærilega. Erfiðu minningarnar og sársaukinn peim tengdur gefur tilefni til að fjalla sérstaklega um samspil

44 Auður Jónsdóttir, Stóri skjálfti, bls. 168.

45 Minningar Sögu um Berg og fortíð peirra kallast glögglega á við brot úr söngtextanum The Way We Were sem Barbra Streisand söng svo eftirminnilega á sínum tíma: Memories May be beautiful and yet/ What's too painful to remember/ We simply choose to forget / For it's the laughter/ We will remember/ Whenever we remember/ The way we were. 
tráma og minnis og skal pað pví gert áður en rætt verður nánar um áföllin í lífi Sögu, hvernig hún minnist peirra og hvaða áhrif pau hafa haft á hana og hennar nánustu.

\section{Minnið er eins og laukur}

Рað er algengt að fólk takist á við ýmsa atburði fortíðarinnar með afneitun og reyni að leiða hjá sér erfiðar minningar en í sumum tilvikum getur pað grafið pær svo rækilega niður að pær gleymast alveg. Til dæmis er vel pekkt að fólk geti gleymt trámatískum atburði að hluta eða í heilu lagi. ${ }^{46}$ Í tilviki Sögu er afturvirka minnisleysið bæði afleiðing floganna og einkenni áfallastreituröskunar sem tráma getur leitt af sér. Eftir pví sem líður á söguna verður nefnilega ljóst að Saga hefur upplifað ýmis trámu en pau helstu tengjast veikindum hennar og stjórnleysinu sem pau fela í sér, skilnaðinum við Berg, alvarlegum veikindum sonar hennar og systurmissi í bernsku. Trámatískur atburður felur í sér sársaukafulla reynslu en dæmi um slíka atburði eru alvarleg veikindi og að sjá einhvern nákominn sér láta lífið rétt eins og Saga hefur mátt reyna. ${ }^{47}$ Tráma eða sálrænt áfall ${ }^{48}$ hefur verið skilgreint sem svo að „reynsla verði áfall pegar menn ná ekki að skilja - p.e. ná ekki að sundurgreina (e. dissociate) - alla pætti hennar““.99 Рað er misjafnt hvernig fólk vinnur úr trámatískri reynslu. Með hjálp sköpunarhæfni og sveigjanleika tekst sumum að laga sig að skelfilegum aðstæðum en aðrir kunna að próa með sér áfallastreituröskun (e. post-traumatic stress disorder $(P T S D))^{50}$ en hún hefur verið skilgreind á pá leið að persóna „reyndi, varð vitni að eða mætti atburði eða atburðum sem fólu í sér raunverulegan eða yfirvofandi dauða,

46 Bessel A. van der Kolk, The Body Keeps the Score. Brain, Mind, and Body in the Healing of Trauma, New York: Penguin Books, 2015, bls. 191.

47 Sjá til dæmis Bessel A. van der Kolk, „Posttraumatic stress disorder and the nature of trauma“, Dialogues in clinical neuroscience 2: 1/2000, bls. 7-22, hér bls. 7. Dæmi um aðra trámatíska atburði eru líkamsárásir, kynferðislegt ofbeldi, stríð, slys og náttúruhamfarir. Sama heimild, bls. 7.

48 Hér verður jöfnum höndum talað um tráma og áfall sem sama fyrirbærið.

49 Bergljót Soffía Kristjánsdóttir, „Óvistlegar herbergiskytrur. Um rými og annan hluta bókarinnar Af manna völdum“, Hug/raun. Nútímabókmenntir og bugren freðð, Reykjavík: Háskólaútgáfan, 2015, bls. 111-132, hér bls. 129.

50 Bessel A. van der Kolk og Alexander C. McFarlane, „The Black Hole of Trauma“, Traumatic Stress. The Effects of Overwhelming Experience on Mind, Body, and Society, ritstjórar Bessel A. van der Kolk, Alexander C. McFarlane og Lars Weisaeth, 1996, bls. 3-23, hér bls. 3 . 
alvarlegan skaða eða ógnun við heilsu persónunnar sjálfrar eða annarra“. ${ }^{51}$ Раð er afar misjafnt hvernig fólk með áfallastreituröskun minnist sálrænna áfalla. Sumir virðast til dæmis muna eftir atburðinum í smæstu smáatriðum á meðan reynslan er alveg hulin öðrum. Pá eru pað peir sem segjast jafnvel upplifa hvort tveggja; peir muna í fyrstu ekki eftir áfallinu en síðan rifjast pað upp smátt og smátt og minningin af pví verður æ nákvæmari. ${ }^{52}$

Í bókinni The Body Keeps the Score bendir geðlæknirinn Bessel van der Kolk á að hvort við munum eftir tilteknum atburði yfir höfuð og hversu nákvæmlega fari einkum eftir pví hversu mikið atburðurinn kemur okkur persónulega við og hve tengdar minningarnar eru tilfinningum en pví sterkari tilfinningaleg tengsl pví meiri líkur eru á að atburðurinn geymist í minninu. ${ }^{53}$ Samkvæmt van der Kolk er petta pó aðeins satt og rétt upp að ákveðnu marki pví pegar einstaklingur stendur andspænis skelfingu, einkum peirrar sem skapast vegna óumflýjanlegs áfalls, bregst minniskerfið. ${ }^{54}$ Fyrir vikið minnist einstaklingurinn áfallsins á annan hátt en annarrar reynslu. Van der Kolk telur semsagt að trámaminni, pað er „minni um atburð sem hefur orðið tiltekinni persónu áfall" ${ }^{\text {55 }}$, sé öðruvísi en annað minni. ${ }^{56}$

51 Bergljót Soffía Kristjánsdóttir, „Óvistlegar herbergiskytrur“, bls. 129. Lýsingin er bein pýðing Bergljótar Soffíu úr grein eftir Bessel A. van der Kolk, James W. Hopper og Janet E. Osterman en á ensku hljómar tilvitnunin svona: „the person experienced, witnessed or was confronted with an event or events that involved actual or threatened death or serious injury, or a threat to the physical integrity of self or others“. Bessel A. van der Kolk, James W. Hopper og Janet E. Osterman, „Exploring the Nature of Traumatic Memory. Combining Clinical Knowledge with Laboratory Methods“, Trauma and Cognitive Science. A Meeting of Minds, Science and Human Experience, ritstjórar Jennifer J. Freyd og Anne P. DePrince, New York: The Haworth Maltreatment og Trauma Press, 2001, bls. 9-32, hér bls. 11.

52 Bessel A. van der Kolk, "Trauma and Memory“, Traumatic Stress. The Effects of Overwhelming Experience on Mind, Body, and Society, ritstjórar Bessel A. van der Kolk, Alexander C. McFarlane og Lars Weisaeth, 1996, bls. 279-302, hér bls. 282-284. Tekið skal fram að algengur fylgifiskur tráma eru ágengar minningar um atburðinn. Slíkar minningar geta tekið á sig mörg ólík form en til dæmis geta pær falið í sér tíð endurlit, tilfinningar eins og reiði og kvíða, martraðir, svefnleysi og ýmis líkamleg einkenni. Bessel A. van der Kolk og Alexander C. McFarlane, „The Black Hole of Trauma“, bls. 5-15.

53 Bessel A. van der Kolk, The Body Keeps the Score, bls. 177. Hann nefnir til dæmis að flestir muni enn atburðina sem áttu sér stað 11. september 2001 en ekki endilega hvað gerðist 10. september sama ár. Sama heimild, bls. 177.

54 Sama heimild, bls. 178.

55 Bergljót Soffía Kristjánsdóttir, „Óvistlegar herbergiskytrur“, bls. 129.

56 Bessel A. van der Kolk, „Trauma and Memory“, bls. 282. van der Kolk og samstarfsmenn hans hafa útbúið mælitæki sem peir kalla Traumatic Memory Inventory 
Van der Kolk og samstarfsmenn hans hafa lengi rannsakað tráma og minni en rannsóknir peirra byggja á viðtölum við skjólstæðinga, lífeðlislegum rannsóknum og reynslu annarra geðlækna og sálfræðinga. ${ }^{57}$ Peir líta svo

sem er ætlað að kanna muninn á trámaminningum og minningum sem ekki tengjast tráma. Bessel A. van der Kolk, James W. Hopper og Janet E. Osterman, „Exploring the Nature of Traumatic Memory. Combining Clinical Knowledge with Laboratory Methods", Journal of Aggression, Maltreatment and Trauma 4: 2/2001, bls. 9-31, hér bls. 14-18. Vert er að nefna að Bergljót Soffía Kristjánsdóttir, Dagný Kristjánsdóttir, Guðrún Steinpórsdóttir og Sigrún Margrét Guðmundsdóttir hafa allar fjallað um kenningar Bessel A. van der Kolk og samstarfsmanna hans í tengslum við bókmenntir og/eða kvikmyndir. Sjá Bergljót Soffía Kristjánsdóttir, „Óvistlegar herbergiskytrur“, bls. 129-131; Dagný Kristjánsdóttir, „Barnaleikur. Um tráma, minni og gleymsku í Jójó eftir Steinunni Sigurðardóttur“, Skírnir vor/2013, bls. 178-195, hér bls. 184188; Guðrún Steinpórsdóttir, „,sambýliskonur [...] í sama kroppi, í sama höfði, í sama blóði“. Um samband Dísu og Gríms í Dísusögu eftir Vigdísi Grímsdóttur“, Ritið 1/2019, bls. 41-78, hér bls. 51-53; Sigrún Margrét Guðmundsdóttir, „„Hann er bara á vondum stað“. Reimleikahús í kvikmyndinni Rökkri eftir Erling Óttar Thoroddsen“, bls. 132 og Sigrún Margrét Guðmundsdóttir, „,'Tveggja hæða hús á besta stað í bænum“. Um Húsið eftir Egil Eðvarðsson“, Ritið 2/2019, bls. 135172, hér bls. 157-160. Pá skal tekið fram að hérlendis hafa ýmsir skrifað um tráma og íslenskar nútímabókmenntir en til viðbótar við fyrrnefndar greinar má nefna: Alda Björk Valdimarsdóttir, „Vera Hertzsch. Dæmisögur um siðferði skálds“, Skírnir vor/2007, bls. 36-60; Dagný Kristjánsdóttir, „Sár. Um stríð, trámu og salamöndrur“, Rúnir. Greinasafn um skáldskap og freðastörf Álfrúnar Gunnlaugsdóttur, ritstjóri Guðni Elísson, Reykjavík: Bókmenntastofnun Háskóla Íslands, 2010, bls. 17-30; Gunnpórunn Guðmundsdóttir, „Tregðan í frásögninni. Yfir Ebrófljótið“, Rúnir. Greinasafn um skáldskap og freðastörf Álfrúnar Gunnlaugsdóttur, ritstjóri Guðni Elísson, Reykjavík: Bókmenntastofnun Háskóla Íslands, 2010, bls. 129-141; sama, „Vitnisburður um veruleikann. Um nokkur íslensk sjálfsævisöguleg verk 2010-2015, Skirnir haust/2015, bls. 304-320, hér bls. 311-313 og Daisy Neijmann, „Hringsól um dulinn kjarna. Minni og gleymska í príleik Ólafs Jóhanns Sigurðssonar“, Ritið 1/2012, bls. 115-139. Auk pess skal nefnt að Gunnpórunn Guðmundsdóttir fjallar um tráma og minni í greininni „Blekking og minni. Binjamin Wilkomirski og helfararfrásagnir“, bls. 39-51.

57 Sjá til dæmis Bessel A. van der Kolk, „Trauma and Memory“, bls. 287; Bessel A. van der Kolk, The Body Keeps the Score, bls. 178-185; Bessel A. van der Kolk, James W. Hopper og Janet E. Osterman, „Exploring the Nature of Traumatic Memory. Combining Clinical Knowledge with Laboratory Methods“, bls. 9-31; Bessel A. van der Kolk og Onno van der Hart, „The Intrusive Past. The Flexibility of Memory and the Engraving of Trauma“, Trauma. Explorations in Memory, ritstjóri Cathy Caruth, Baltimore: The Johns Hopkins University Press, 1995, bls. 158-182. Tekið skal fram að Van der Kolk og félagar hans byggja meðal annars pekkingu sína á tráma og minni á skrifum Pierre Marie Félix Janet (1859-1947) frá lokum nítjándu aldar. Sjá til dæmis Bessel A. van der Kolk og Onno van der Hart, „The Intrusive Past. The Flexibility of Memory and the Engraving of Trauma“, bls. 158-182. Á íslensku hefur Dagný Kristjánsdóttir gert góða grein fyrir skrifum van der Kolk og 
á að trámaminni sé brotakenndara en annað minni. Í upphafi eru brotin sem einstaklingur man gjarnan einangruð og tengd ákveðinni skynjun, til dæmis ímynd, lykt, hljóði, hreyfingu eða tilfinningum $;^{58}$ en „umhverfið getur vakið upp minningar um áfallið pegar pað tengist pessum afmörkuðu atriðum“. .59 Pá er algengt að einstaklingur geti ekki sett í orð hvað hefur komið fyrir hann; hann hafi með öðrum orðum ekki frásagnarminni (e. narrative memory) um áfallið og skiptir pá engu hvort hann hafi alltaf vitað að hann hafi orðið fyrir tráma eða hvort trámatíska reynslan hafi í fyrstu verið honum hulin en rifjast upp síðar meir. ${ }^{60}$ Bókmenntafræðingurinn Cathy Caruth er á svipuðum slóðum. ${ }^{61}$ Hún segir að einkennandi fyrir tráma sé að pað rjúfi sögu og tíma. Einstaklingur meðtaki ekki trámatíska atburðinn til fulls pegar hann á sér stað en trámað snúi síðan aftur og ásæki hann síðar meir til dæmis

van der Hart um kenningar Janet. Dagný Kristjánsdóttir, „Barnaleikur. Um tráma, minni og gleymsku í Jójó eftir Steinunni Sigurðardóttur“, bls. 184-188.

58 Bessel A. van der Kolk, James W. Hopper og Janet E. Osterman, „Exploring the Nature of Traumatic Memory. Combining Clinical Knowledge with Laboratory Methods“, bls. 16.

59 Bergljót Soffía Kristjánsdóttir, „Óvistlegar herbergiskytrur“, bls. 129.

60 Bessel A. van der Kolk, James W. Hopper og Janet E. Osterman, „Exploring the Nature of Traumatic Memory. Combining Clinical Knowledge with Laboratory Methods“, bls. 16. Petta kallast á við kenningar Elaine Scarry um sársauka en hún segir að sársauki - einkum sársauki vegna pyntinga - „eyðileggi heiminn“ bað er að segja komi í veg fyrir að hægt sé að færa í orð og lýsa líðaninni og par með merkingunni sem sársaukinn veldur. Elaine Scarry, The Body in Pain. The Making and Unmaking of the World, New York: Oxford University Press, USA, 1987, bls. 4. Dagný Kristjánsdóttir hefur fjallað um pversögn trámans en hún segir: „Trámað kemur fólki að óvörum en að auki felur pað í sér eitthvað yfirgengilegt, eitthvað ofbjóðanlegt, og spyrjum við hvað pað sé verður oft fátt um svör. Pað er vegna pess að hin trámatíska reynsla er ekki aðgengileg. Fólk veit af áfallinu og vill eða verður að segja frá pví sem gerðist, bera vitni, vara aðra við og/eða kalla einhvern til ábyrgðar. En stundum hefur fólk óljósa mynd af pví sem gerðist. Раð er eins og pað sé bæði til staðar og fjarverandi. Рað vantar eitthvað í söguna. Pversögn trámans er einmitt pað minnisleysi og rangminni sem gera frásögn fórnarlambsins ótrúverðuga.“ Dagný Kristjánsdóttir, „Sár. Um stríð, trámu og salamöndrur“, bls. 23. Í skrifum sínum um tráma vísar Dagný til greinar Janet Walker, „The Traumatic Paradox. Autobiographical documentary and the psychology of memory“, Contested Pasts. The Politics of Memory, ritstjórar Katharine Hodgkin og Susannah Radston, New York: Routledge, 2003, bls. 117-132.

${ }^{61}$ Mikið hefur verið skrifað um tráma og bókmenntir en Cathy Caruth er frumkvöðull á pví sviði. Hún hefur til dæmis skrifað bækurnar Unclaimed Experience. Trauma, Narrative and History (1996) og Listening to Trauma. Conversations with Leaders in the Theory and Treatment of Catastrophic Experience (2014) auk pess sem hún ritstýrði greinasafninu Trauma. Explorations in Memory (1995). 
í ímyndum, draumum, óvelkomnum endurlitum og hugsunum. Minningin um trámað sé pví ekki aðgengileg á sama hátt og aðrar minningar. ${ }^{62}$

Skjólstæðingar van der Kolk og félaga hafa lýst upplifun sinni af endurheimtingu trámatískra minninga svo að í upphafi hafi peir munað trámað í formi tiltekinnar skynjunar sem hafi birst peim í leiftrum eða stökum brotum. Til að byrja með hafi leiftrin verið bundin einu skynáreiti í senn en eftir pví sem meðvitundin um trámað hafi orðið meiri pví fleiri skynáreiti hafi komið til peirra samtímis. Pá hafi hæfnin til að segja frá trámanu, frásagnarminnið, aukist jafnt og pétt. ${ }^{63}$ Bessel A. van der Kolk og Otto van der Hart hafa einmitt bent á að eitt einkenni trámaminnis séu erfiðleikar með að búa til heildstæða frásögn af áfallinu pví til að byrja með geti hún tekið margar klukkustundir í flutningi en eftir pví sem einstaklingur nær betri tökum á minningunni tekst honum að móta hana og segja frá henni á mun styttri tíma. ${ }^{64}$ Pegar fólk fer að öðlast heildstæðari mynd af pví sem gerst hefur, byrjar að raða minningabrotunum saman og segja frá trámanu verður pað smám saman hluti af sjálfsævisögulegu minni pess. ${ }^{65} \mathrm{Og}$ rétt eins og gerist með annað sjálfsævisögulegt minni er pá líklegt að einstaklingur noti ímyndunaraflið til að fylla inn í eyðurnar til að búa til enn fyllri og skýrari mynd af pví sem hefur hent hann.

62 Cathy Caruth, „Trauma and Experience. Introduction“, Trauma. Explorations in Memory, ritstjóri Cathy Caruth, Baltimore og London: The Jones Hopkins University Press, 1995, bls. 3-12, hér bls. 4-5. Sem dæmi um góða íslenska bókmenntagreiningu á pessum nótum má nefna grein Gunnpórunnar Guðmundsdóttur, „Tregðan í frásögninni. Yfir Ebrófljótið“, bls. 129-141. Tekið skal fram að Sigrún Margrét Guðmundsdóttir hefur gert góða grein fyrir hvernig myndmál áfallafræða er að einhverju leyti sótt til gotneskrar hefðar en hún hefur til dæmis fjallað um hvernig tráma birtist gjarnan í formi afturgangna í kvikmyndum og bókmenntum. Sigrún Margrét segir: „Reimleikarnir hegða sér á sama hátt og áföll, eitthvað hrindir af stað draugum fortíðarinnar sem taka að ásækja sögupersónur. Heilinn verður andsetinn af minningum sem birtast sem reimleikar í húsum manna í skáldskap. Rof verður á milli veruleikans eins og persónurnar pekkja hann vegna pess að reimleikarnir tilheyra öðru sviði.“ Sigrún Margrét Guðmundsdóttir, „„Hann er bara á vondum stað“. Reimleikahús í kvikmyndinni Rökkri eftir Erling Óttar Thoroddsen“, bls. 132-133. Sjá einnig umfjöllun Sigrúnar Margrétar um tengsl áfalla við gotneskt myndmál, „,'Tveggja hæða hús á besta stað í bænum“. Um Húsið eftir Egil Eðvarðsson“, bls. 156-163.

63 Bessel A. van der Kolk, „Trauma and Memory“, bls. 287-289; Bessel A. van der Kolk, James W. Hopper og Janet E. Osterman, „Exploring the Nature of Traumatic Memory. Combining Clinical Knowledge with Laboratory Methods“, bls. 16.

64 Bessel A. van der Kolk og Onno van der Hart, „The Intrusive Past. The Flexibility of Memory and the Engraving of Trauma“, bls. 163.

65 Sama heimild, bls. 176. 
Ímyndunaraflið getur einnig haft áhrif á minningar einstaklings um tráma pegar pað er paggað niður og ekki rætt, hvort sem viðkomandi kýs pað sjálfur eða getur ekki nálgast minningar um pað. Dori Laub, sérfræðingur í trámafræðum ${ }^{66}$, segir í skrifum um tráma, með hliðsjón af helfararfrásögnum, að peir eftirlifendur helfararinnar sem kusu að pegja um reynslu sína hafi orðið fórnarlömb brenglaðs minnis. Í pögninni hafi skapast endalausar ranghugmyndir og sjálfsblekkingar um hvað gerðist í raun og veru en pví lengur sem viðkomandi pagði um reynslu sína pví afbakaðri urðu hugmyndir hans um hana. Í sumum tilvikum urðu minningarnar svo skakkar að einstaklingurinn efaðist um að trámatísku atburðirnir hefðu í raun átt sér stað. ${ }^{67}$ Pótt skrif Laub eigi við um eftirlifendur helfararinnar má yfirfæra bau á aðra polendur tráma og pær ranghugmyndir sem peir kunna að próa með sér í kjölfar áfalls. ${ }^{68}$

Eins og fyrr var nefnt er allt minni Sögu afar brotakennt eftir flogaköstin en henni reynist erfiðast að ná upp í vitundina minningum um trámatíska reynslu. Sársaukinn sem hún finnur fyrir pegar hún reynir að rifja upp erfiðar minningar vitnar um að hún veit aðeins að eitthvað hræðilegt hefur gerst í fortíðinni en ekki nákvæmlega hvað eða hvers vegna. Hún hefur semsagt ekki frásagnarminni um atburðina. Minnið hjá Sögu er samt „eins og laukur, við hvert lag sem er skrælt í burtu kemur nýtt í ljós“669 pað er að segja

66 Geðlæknirinn og sálgreinirinn Dori Laub (1937-2018) var brautryðjandi í trámarannsóknum en hann lagði sig einkum fram við að kanna tráma með hliðsjón af helfararfrásögnum. Sjálfur lifði hann helförina af sem barn en á fullorðinsárum tók hann yfir hundrað viðtöl við eftirlifendur helfararinnar. Hann skrifaði meðal annars bókina Testimony. Crises of Witnessing in Literature, Psychoanalysis and History (1991) í samvinnu við Shoshana Felman. Í skrifum um tráma lagði Laub áherslu á mikilvægi pess að fólk fengi tækifæri til að tala um trámað sem pað hefði upplifað og að hlustað væri gaumgæfilega á pað og reynsla pess viðurkennd. Samanber Dori Laub, „Truth and Testimony. The Process and the Struggle“, Trauma. Explorations in Memory, ritstjóri Cathy Caruth, Baltimore og London: The Jones Hopkins University Press, 1995, bls. 61-75.

67 Dori Laub, „Truth and Testimony. The Process and the Struggle“, bls. 64.

68 Í sumum tilvikum kunna ranghugmyndirnar að verða svo ríkjandi að einstaklingur kennir sjálfum sér um trámatíska atburðinn. Í pessu samhengi má til dæmis minnast peirra brotapola nauðgana sem telja sig ábyrga fyrir glæpnum sem á peim er framinn. Samanber Rannveig Sigurvinsdóttir, „,,Pú veist pú vilt pað“. Skýringar á kynferðisofbeldi á samfélagsmiðlum“, Ritið 3/2018, bls. 151-171, hér bls. 153.

69 Hér er vitnað beint til orða úr hugvekju eftir Auði Jónsdóttur sem fjallar um skrif og minni; í réttu samhengi hljóma orðin svona: „Mig rámar í danska skáldkonu sem minntist vinar síns sem hefur alltaf skrifað sjálfsævisögulega um barnæskuna og man fyrir vikið meira en flestir eftir barnsárunum pví minnið er eins og laukur, 
eitt leiftur sem tengist erfiðum atburði - eða tráma - glæðir fleiri leiftur um atburðinn. Pá kallar einnig ein minning um tráma á minningu um annan erfiðan atburð; en minningin um pað alsárasta - systurmissinn - verður síðast ljós. Anne Whitehead, höfundur bókarinnar Trauma Fiction, segir að skrif um tráma líkist gjarnan einkennum tráma sem gerir pað að verkum að skipun atburða sé oft ekki í tímaröð og endurtekningar og stefnuleysi sé einkennandi. ${ }^{70}$ Pað á vel við um Stóra skjálfta en í heilu lagi minnir frásögnin á tilraun einstaklings til að búa til heildstæða frásögn af fyrri áföllum.

Ýmsir pættir úr umhverfinu ýfa upp brotakenndar minningar Sögu um erfiðleikana í fortíð hennar en hún er pó ekki alltaf meðvituð um að minningabrotin sem vakna tengist ákveðnum áföllum. Par með verða bæði Saga og lesendur að tengja saman ólíkar hugsanir hennar, leiftur sem henni birtast og sársauka peim tengdum til að öðlast skilning á hvað hefur gerst í fortíðinni. Til að skoða petta ferli betur má taka dæmi af pví hvernig vitneskjan og minningar um veikindi Ívars verða Sögu sífellt skýrari eftir pví sem líður á söguna.

Pegar Saga er nýkomin heim af spítalanum eftir flogaköstin leiða óhreinindi í glugga á heimili hennar hugann að myglusvepp en lengra nær hugsunin ekki pví „[s]tingurinn í höfðinu magnast, [og] óp brýst upp úr líkamanum“ (31). Líkamlegi sársaukinn vitnar um að minning um myglusvepp tengist áfalli. Stuttu síðar er lesendum gefin vísbending um að Saga óttist um líf Ívars pví pegar henni verður litið út um glugga og sér stálpuð börn stytta sér leið yfir stóra umferðargötu fyllist hún skelfingu um að sonur hennar kunni að apa hegðunina eftir. Henni finnst hún knúin til að stöðva hegðun krakkanna pví eins og hún hugsar sjálf: „Ég verð að stoppa petta, stoppa, stoppa, stoppa!“ (33). Sítekningin á orðinu „stoppa“ minnir á öran hjartslátt og undirstrikar pannig óttann sem Saga finnur fyrir. ${ }^{71}$ Hræðslan

við hvert lag sem er skrælt í burtu kemur nýtt í ljós. Pannig getum við verið líkust vísindamönnum ef við skrifum upp úr eigin minningum, að rannsaka vitundina, og pannig hjálpa skrif til dæmis eldra fólki með elliglöp, rétt eins og bau geta hjálpað barni eftir áfall.“ Auður Jónsdóttir, „Við erum stöðugt að skálda lífið“, bls. 112. Að líkja minninu við lauk minnir á orð Shrek, úr samnefndri kvikmynd frá árinu 2001, um að tröll hafi ótal lög eins og laukar: „ogres are like onions! [...] Onions have layers. Ogres have layers." Ummæli Shreks gefa til kynna að tröll - rétt eins og minnið og laukar - séu margpættari en pau kunna að virðast vera við fyrstu sýn.

70 Anne Whitehead, Trauma Fiction, Edinburgh: Edinburgh University Press, 2004, bls. 3 .

71 Nefnt skal að Edgar Allan Poe notar petta stílbragð í smásögunni „Hjartslátturinn“ en par styttast setningar sögumannsins eftir pví sem hann verður óttaslegnari pannig að pær minna á öran hjartslátt. Edgar Allan Poe, „Hjartslátturinn“, pýðandi 
er síðan staðfest enn frekar með lýsingu á óbærilegum verkjum: „Petta er svo djöfullega sárt. Stingur ristir sundur höfuðið. Ég verð að hætta að hugsa svona. Hætta pví! Núna! Höfuðið er að springa, prýstingurinn hræðilegur. Ég er að deyja“ (33). Sársaukinn sem Saga finnur fyrir er sá hinn sami og hugsunin um myglusveppinn kallaði fram - í báðum tilvikum er um sting í höfði að ræða - en pví má ætla að óttinn um Ívar tengist myglusveppnum en einskorðist ekki við almenna hræðslu foreldris um að barn kunni ekki allar umferðarreglur til hlítar. Pau tengsl eru síðan staðfest tveimur köflum síðar pegar Jóhanna, systir Sögu, rifjar upp alvarleg veikindi Ívars og að hún hafi vonað að pau stöfuðu af myglusveppnum í íbúðinni sem Saga og Bergur bjuggu í. Pá verður fyrst ljóst að Saga man ekki eftir veikindum Ívars en orð systur hennar ýfa upp hjá henni brotakennd leiftur tengd tilfinningum og stökum ímyndum:

Skelfingin frystir hverja frumu í líkama mínum. (65)

Hvert orð hljómar eins og slitur úr gleymdum draumi; pað hreyfir við minningunum svo óljósum svipmyndum bregður fyrir, surg í Ívari í myrkri um nótt. Er petta einhver bíomynd sem ég á að hafa séð? (66)

Mig langaði að vita meira, miklu meira, um pennan hroða í Ívari. Mig rámar aðeins óljóst í að hafa farið með hann á barnaspítalann, man samt eftir pví að hafa staðið yfir honum par sem hann lá á bekk með undarlegt tæki fyrir vitunum og andaði að sér einhverju sem minnir mig á ískristalla, við minningarleiftrið pyngist höfuðið eins og svampur í slýtjörn. Mér sortnar fyrir augum, óttinn blindar mig. [...]

Ég reyni að sjá atburðina fyrir mér og pað verður til pess að ég anda sjálf að mér ískristöllum, líkaminn hafnar myndinni, pessi mynd á ekki heima í höfðinu á mér, prumar hjartað og brýst um eins og niðurreyrður fangi. Ég reyni að ná valdi á andardrættinum, tekst pað ekki fyrr en myndin fjarar út. (75)

Saga veit að hún á að muna eftir veikindum Ívars og porir pess vegna ekki að viðurkenna minnisleysið fyrir systur sinni. Leiftrin sem vakna eiga pað sameiginlegt að tengjast ákveðinni skynjun; tilfinningu, hreyfingu og ímynd;

Pórbergur Pórðarson, Ólíkar persónur. Fyrstu ritverk i óbundnu máli 1912-1926, Reykjavík: Ljóðhús, 1976, bls. 203-212, hér einkum bls. 211-212. 
en Sögu tekst pó ekki að setja saman heildstæða minningu. Lýsingin á líkamlegri vanlíðan hennar ber vott um að reynslan af veikindum Ívars sé of sársaukafull til pess að hún geti náð minningunni fullmótaðri upp í meðvitundina. Henni tekst aðeins að muna að Ívar hefur verið veikur en ekki hvað amaði að.

Saga öðlast ekki fullkomið frásagnarminni um trámað fyrr en hún játar minnisleysið fyrir systur sinni og biður hana um að fylla inn í minniseyðurnar. Pá loksins fær hún á hreint að pegar Ívar fær bólgu í barkann parf hann að fara á barnaspítalann „pví pað getur lokast fyrir öndunarveginn“ (170) og að „í eitt skipti mátti ekki tæpara standa að koma honum á spítalann, hann purfti að fara með sjúkrabíl“ (170). Frásögn Jóhönnu vekur upp skýra minningu hjá Sögu, hún man veikindi Ívars og að Bergur hafi ekki brugðist eins hratt við aðstæðum og hún taldi æskilegt pegar kalla purfti á sjúkrabíl fyrir Ívar. En pótt minning um einn trámatískan atburð sé orðin hluti af sjálfsævisögulega minni Sögu man hún ekki allt. Hún veit til dæmis ekki hvers vegna hún og Bergur eru skilin. Samkvæmt Jóhönnu var pað hennar ákvörðun, hún hafði myndað ópol gagnvart Bergi en umfram allt hafði hún ekki treyst honum fyrir Ívari eftir að hann greindist með barkabólguna. Раð má pví segja að eitt tráma; alvarleg veikindi sonar; hafi verið orsök annars; skilnaðar Sögu og Bergs. Tedda, vinkona Sögu, telur að ástæðan fyrir pví að Saga finni fyrir jákvæðum tilfinningum í garð Bergs og vilji hann aftur eftir flogaköstin sé einkum sú að hún treystir ekki sjálfri sér fyrir barninu vegna eigin veikinda. En hvers vegna treysti Saga ekki Bergi fyrir flogaköstin? Í samtali við Jóhönnu verður ljóst að best falda trámað úr fortíð Sögu, systurmissirinn, kann að vera orsökin fyrir vantraustinu. Frásagnir Jóhönnu af fortíðinni draga bæði fram hvaða áhrif tráma getur haft á heila fjölskyldu og ekki síst hve óáreiðanlegt fyrirbæri minnið er.

\section{Kjarni lauksins}

Раð er afar erfitt að orða trámatíska reynslu pví eins og bent hefur verið á tekur pað einstakling tíma að ná tökum á frásagnarminninu og búa til heildstæða frásögn um áfallið. Engan skyldi pví undra að sumir peirra sem eiga erfiða reynslu að baki kjósi að nýta sér pögnina og pegi um trámað gagngert til að vernda sjálfa sig og ná stjórn á sorginni, sársaukanum, óttanum og sektarkenndinni sem tengjast gjarnan áfallinu. Pótt pögnin geti orkað sem varnarhjúpur og par með verið bjargræði getur hún einnig haft neikvæðar afleiðingar pví svo lengi sem einstaklingur pegir yfir leyndarmáli eða 
bælir upplýsingar og/eða minningar um erfiða reynslu er hann að sínu leyti í stríði við sjálfan sig. Рað tekur nefnilega ómælda orku að fela kjarnatilfinningar (e. core feelings) í sömu mund og pað getur haft ýmis neikvæð áhrif á líkamann og geðheilsuna. Pegar einstaklingur viðurkennir rót vandans getur hann orðið meðvitaðri um að tiltekin vanlíðan og ákveðnar tilfinningar séu afleiðingar áfallsins en fyrir vikið er hann betur í stakk búinn til að takast á við trámað og láta sér líða betur. ${ }^{72}$

Petta á vel við um Sögu bví eftir pví sem hún nær tökum á fleiri minningum um fyrri trámu og gefur sér tíma og rými til að hugsa um pau pví betur gengur henni að skilja sjálfa sig, hegðun sína og líðan auk pess sem sársaukinn minnkar til muna. Tráma hefur sjaldnast aðeins áhrif á einstaklinginn sem fyrir pví verður heldur snertir pað einnig oftast pá sem næst honum standa en í sumum tilvikum getur áfall eins rifjað upp áfall annars. ${ }^{73}$ Með tilliti til Sögu er ljóst að flogaköstin hafa ekki aðeins áhrif á hana sjálfa heldur einnig á daglegt líf flestra fjölskyldumeðlima hennar og líðan peirra. Af peim verður móðir hennar, Kristín, verst úti pví veikindin ýfa upp minningar um annað fjölskylduáfall sem markvisst hefur verið paggað niður. ${ }^{74}$

Lýsingar á útliti Kristínar og líkamsástandi gefa vísbendingar um vanlíðan hennar vegna veikinda Sögu: hún er „föl af áhyggjum og samankreppt“ (18), er með „[á]hyggjuhrukk[u] yfir íbjúgu nefinu“ (20) og [h]árinu [er]

72 Bessel A. van der Kolk, The Body Keeps the Score, bls. 233-234; Maria Ritter, „Silence as the Voice of Trauma“, The American Fournal of Psychoanalysis 74: 2/2014, bls. 176194, hér bls. 180; Rita Charon, Narrative Medicine, Oxford: Oxford University Press, 2006, bls. 65; Aphrodite Matsakis, „Trauma and It's Impact on Families“, Handbook of Stress, Trauma, and the Family, ritstjóri Don R. Catherall, New York og Hove: Brunner-Routledge, 2004, bls. 15-32, hér bls. 21. Petta kallast á við reynslu Dori Laub af pví að taka viðtöl við eftirlifendur helfararinnar. Í skrifum um pá og trámu peirra segir Laub að til að komast lífs af hafi pað verið polendunum nauðsynlegt að fá tækifæri til að segja sögu sína til fulls. Pá bendir hann á að innra með hverjum eftirlifanda búi pörf fyrir að segja frá reynslu sinni til pess að skilja sjálfan sig betur og halda áfram með lífið. Hann nefnir engu að síður að til pess að pað sé mögulegt purfi viðkomandi að gangast við draugum fortíðarinnar og ræða pá en ekki grafa pá niður - pað geti pó tekið áratugi. Dori Laub, „Truth and Testimony. The Process and the Struggle“, bls. 63-64.

73 Aphrodite Matsakis, „Trauma and It's Impact on Families“, bls. 15.

74 Katrín Jakobsdóttir hefur bent á að eitt af leiðarminnunum í verkum AuðarJónsdóttur eru samskipti dætra og mæðra með öllum peim vandræðum sem peim fylgja. Katrín Jakobsdóttir, „Mömmur, ömmur, dætur. Hugleiðing um sköpun kvenna í sögum Auðar Jónsdóttur“, Skirnir haust/2014, bls. 301-322, hér bls. 301. Pótt Stóri skjálfti hafi komið út eftir að Katrín skrifaði sína grein á sagan pað sameiginlegt með fyrri verkum Auðar að fjallað er um flókin samskipti mæðra og dætra en pau eru pó ekki sérstaklega til umfjöllunar í pessari grein. 
hrúgað í sátu en ekki blásið upp í úthugsaða lokka eins og vanalega“ (20). Pá getur hún „ekki dulið preytuna, streitan situr föst í andlitsdráttunum“ (55) og „hana verkjar í kroppinn [...] [en hana] verkar alltaf pegar hún er preytt“ (20). ${ }^{75}$ Fljótlega eftir að Saga útskrifast af spítalanum lætur Kristín sig hverfa en vegna minnisvandræðanna veit Saga ekki hvers vegna. Hvarfið kemur hvorki föður hennar né systkinum á óvart pví í ljós kemur að petta er ekki í fyrsta skiptið sem Kristín hverfur. Veikindi Sögu hafa vakið upp minningar hennar um fyrri áföll og um leið ýft upp neikvæðar tilfinningar og vanlíðan sem peim tengjast. Áföllin sem hér um ræðir eru annars vegar fyrri krampaköst Sögu og hins vegar lát Katrínar, systur Sögu, sem lést aðeins tveggja mánaða gömul. Innan fjölskyldunnar hefur aldrei verið rætt um dauða Katrínar og orsök hans heldur hefur pögnin markvisst verið notuð sem vernd, aðferð til að lifa af missinn. Samkvæmt Jóhönnu tókst öllum í fjölskyldunni „að gleyma til að geta haldið áfram að lifa“ (196) pað er öllum nema Kristínu sem „týndist alltaf á haustin, pegar pað tók að dimma“ (196). Pegar Saga fær flogaköstin í upphafi bókar hefur Kristín ekki „týnst“ í fjölda ára. Tíminn, umhverfið og lífshættuleg veikindi Sögu eiga pátt í að vekja upp ótta Kristínar um að missa annað barn sem leiðir til pess að hana verkjar í skrokkinn og tekur upp fyrri iðju pegar hún bókstaflega „forðast að hugsa eða tala um pað sem gerðist, hitta fólk sem tengist atburðinum eða forðast staðinn par sem áfallið átti sér stað“ “. ${ }^{76}$ Hegðun Kristínar er með öðrum orðum skýrt dæmi um áhrif áfallastreituröskunar á einstakling. Ólíkt Sögu sem hefur takmarkaðar minningar um trámu fortíðarinnar man Kristín pau of vel en með pví að láta sig hverfa viðheldur hún pögguninni sem ríkt hefur í fjölskyldunni um fyrri áföll.

Í sögunni gegnir hvarf Kristínar svipuðu hlutverki og flogaköstin pví pað neyðir Sögu til að rifja upp erfiða reynslu úr fortíðinni vilji hún skilja nútíðina. Fyrir flogaköstin ræddi Saga ekki um Katrínu við nokkurn mann og eftir pau man hún ekki einu sinni eftir pví að hafa átt yngri systur. Sem fyrr

75 Tekið skal fram að Auður hefur áður lýst viðbrögðum móður við flogaveiki dóttur en pað gerði hún eftirminnilega í sögunni Ósjálfrátt, par segir að: móðirin „veslaðist upp í hvert skipti sem barnið vaknaði á bráðavaktinni með storknaða froðu í munnvikunum og blóðugan hárflóka eftir að hafa skollið á hausinn úti á miðri götu eða flogið í loftköstum niður stiga. Í hvert skipti sem Mamma fékk símtal frá bráđamóttökunni missti hún matarlystina í prjá daga og svaf ekkert næstu prjár nætur.“ Auður Jónsdóttir, Ósjálfrátt, Reykjavík: Mál og menning, 2012, bls. 96.

76 Berglind Guðmundsdóttir, Edda Björk Pórðardóttir og Agnes Gísladóttir, „Áhrif áfalla á heilsufar kvenna“, Við góða heilsu? Konur og heilbrigði i nútímasamfélagi, ritstjórar Helga Gottfreðsdóttir og Herdís Sveinsdóttir, Reykjavík: Háskólaútgáfan, 2012, bls. 155-172, hér bls. 159. 
verður Jóhanna leiðsögumaður Sögu um fortíðina pví hún tekur að sér að fylla inn í minniseyður systur sinnar og skýra fyrir henni jafnt tildrög dauða Katrínar og áhrif hans á fjölskyldu peirra. Sagan af Katrínu og dauða hennar er mjög gott dæmi um hvernig sama áfallið getur haft ólík áhrif á ólíka aðila og hvernig minningar peirra um pað kunna að vera gjörólíkar. Pað skal nú skoðað með hliðsjón af Sögu og Jóhönnu.

Рað er vel pekkt minnistækni að nota rými til að rifja upp hið liðna. Við upprifjun getur til dæmis verið hentugt að styðjast við húsakynni sem eru viðkomandi vel kunnug en eins og bókmenntafræðingurinn Gunnpórunn Guðmundsdóttir hefur bent á hafa margir höfundar sjálfsævisagna farið pá leið að lýsa æskuheimilum sínum og fetað sig úr einu herbergi í annað í peim tilgangi að rifja upp atburði og fólk úr fortíðinni. ${ }^{77}$ Svipaðri aðferð beitir Jóhanna pví með orðum sínum dregur hún upp skýra mynd af æskuheimili peirra systra svo að minningar um ákveðna lykt, hluti, atvik og fjölskyldumeðlimi vakna hjá Sögu. Í upphafi reynist afstaða Sögu gagnvart minningu Jóhönnu vera tvíbent. Henni finnst æskuheimilið hvort tveggja í senn hryllilegur staður og yndislegur. Tvípætta viðhorfið má hafa sem vísbendingu um hvernig fólk man fortíð sína; oftast skiptast á skin og skúrir í lífi pess en par sem minnið er valkvætt kjósa sumir að muna aðeins hið góða en sneiða hjá hinu ópægilega. Slíkt hefur verið raunin með Sögu sem fyrir flogaköstin vildi aldrei „muna neitt nema pað sem [hentaði] henni“ (257). Pess vegna reynir hún í fyrstu að sporna gegn sársaukafullri frásögn Jóhönnu um dauða systur peirra en áttar sig svo á að ætli hún að ná stjórn á eigin lífi verður hún að muna allt eða í pað minnsta viðurkenna atburði fortíðarinnar.

Jóhanna rekur dauðdaga Katrínar óbeint til drykkju föður peirra og ofbeldisins sem hann beitti móður peirra pegar hann var fullur. Kvöldið sem Katrín dó var hún með stíflað nef. Jóhanna átti að gæta hennar en lét Sögu um pössunina pví hún fór og reyndi að hjálpa mömmu peirra að verjast barsmíðum drukkins föður peirra. ${ }^{78}$ En Katrín var of veik og Saga of ung

77 Gunnpórunn Guðmundsdóttir, „,Minnið er alltaf að störfum“, bls. 138. Um tengsl minnis og staðar sjá einnig Gunnpórunn Guðmundsdóttir og Atli Antonsson, „Combray og Suðursveit. Um minni og proska í Steinarnir tala og Leiðin til Swann“, „að skilja undraljós“. Greinar um Pórberg Pórðarson, verk hans og bugðarefni, ritstjórar Bergljót Soffía Kristjánsdóttir og Hjalti Snær Ægisson, Reykjavík: Bókmennta- og listfræðastofnun Háskóla Íslands, Háskólaútgáfan, 2010, bls. 61-81, hér einkum bls. 68-70.

78 Раð er algengt að börn alkóhólista taki að sér ákveðin hlutverk innan fjölskyldunnar en algengustu staðalmyndir peirra eru hetjan, trúðurinn, blóraböggullinn, týnda barnið og hjálparhellan. Jóhanna virðist vera í hlutverki hetjunnar bví hún hefur verið ofur meðvituð um ástand heimilisins, tekið að sér of mikla ábyrgð og reynt 
til að hún gæti annast hana. Pegar varirnar á Katrínu blánuðu reyndi Saga að hrópa á hjálp en enginn heyrði í henni fyrr en pað var orðið of seint. Eftir barnslátið hætti faðir peirra að drekka, móðir peirra einangraði sig og enginn ræddi um Katrínu.

Pað reynist Sögu erfiðara að ná tökum á frásagnarminninu um lát Katrínar en um veikindi Ívars. Áföllin eru enda ólík, annað er á allra vitorði og um pað er rætt en hitt hefur verið paggað niður í áratugi. Pótt Saga reyni „að púsla saman mynd úr orðum Jóhönnu“ (193) tekst henni ekki að sjá fullmótaða mynd af Katrínu fyrir sér; hún sér aðeins fót hennar en ekki andlit. Minnið um trámað sjálft er einnig brotakennt en brotin sem Saga nemur best eru tilfinningarnar sem tengjast atvikinu; pað er að segja ógnin, hræðslan og umfram allt óbærilegi sársaukinn. ${ }^{79}$ Minningin um dauða Katrínar hefur of lengi verið í felum til pess að Saga nái henni almennilega upp í vitundina en með pví að hlusta á Jóhönnu og leyfa henni að segja frá pessum erfiða atburði verður hún meðvitaðri um fortíðina. Engu að síður blundar í henni efinn; gerðist allt eins og Jóhanna man pað?

Samræður systranna vekja enn á ný upp vangaveltur um minnið og hvernig pað virkar. Eins og fyrr var drepið á hafa rannsóknir sálfræðinga leitt í ljós að menn muna sjaldnast fortíðina nákvæmlega heldur er peim tamt að beita ímyndunaraflinu og fylla inn í eyður og endurskapa pannig hið liðna. ${ }^{80}$ Stundum kann sköpunin pó að ná yfirhöndinni svo að falskar minningar verða til. Раð getur til dæmis gerst pegar einstaklingur segir sjálfum sér sömu söguna aftur og aftur pangað til hann hættir að gera greinarmun á hvað er skáldað og hvað gerðist raunverulega eða var lifað. Hann endar par með á að telja sér trú um að ákveðinn uppspuni sé sannur. Á sama hátt geta aðrir aðilar brenglað minni einstaklings og skapað hjá honum falskar minningar. ${ }^{81}$

að gera sitt til að bæta ástandið á heimilinu til dæmis með pví að hjálpa móður sinni að annast veikt barn og sporna gegn ofbeldi föðurins. Um staðalímyndir barna alkóhólista sjá Sölvína Konráosdóttir, „Sálfræðilegar skýringar á alkóhólisma“, Fíkniefni og forvarnir. Handbók fyrir beimili og skóla, ritstjórar Árni Einarsson og Guðni R. Björnsson, Reykjavík: Fræðslumiðstöðin í forvörnum, 2001, bls. 105-112, hér bls. 108.

79 Auður Jónsdóttir, Stóri skjálfti, bls. 193-194.

80 Samanber til dæmis Daniel L. Schacter og Donna Rose Addis, "The cognitive neuroscience of constructive memory. Remembering the past and imagining the future", Philosophical Transactions of the Royal Society B. Biological Sciences 362: 1481/2007, bls. 773-786, hér bls. 773.

81 Sjá til dæmis Elizabeth F. Loftus, „Creating False Memories“, Scientific American 277: 3/1997, bls. 70-75 og Elizabeth F. Loftus, „Make-Believe Memories“, bls. 869. 
Рað er augljóst að Jóhanna nýtir ímyndunaraflið og fyllir inn í eigin minniseyður pegar hún rifjar upp fortíðina pví hún lýsir til dæmis dauðdaga Katrínar nákvæmlega pótt hún sjálf hafi ekki verið á svæðinu pegar hún lést. Myndin sem Jóhanna dregur upp af föður peirra er bó sú fortíðarminning sem Saga á erfiðast með að sampykkja pví hún stangast hressilega á við minningar hennar um hinn ljúfa og góða föður. Ekki er nóg með að Jóhanna lýsi barsmíðum hans heldur ýjar hún einnig að pví að hann hafi beitt móður peirra kynferðislegu ofbeldi. Hún er pó meðvituð um að minnið er brigðult og slær ýmsa varnagla pess efnis að kannski hafi hún sjálf skapað minningarnar seinna meir:

Stundum finnst mér eins og hann hafi nauðgað henni segir hún loks, hratt eins og henni bjóði við eigin orðum. [...] En hún viti pað samt ekkert fyrir víst. Hún hafi alltaf ímyndað sér allt hið versta pegar hún heyrði lætin, hljóðin, hafi búið til andstyggilegar myndir í huganum. (191)

Ágæta umfjöllun um ólíkar rannsóknir Loftus á fölskum minningum á íslensku má sjá í grein eftir Árna Kristjánsson, „Að skapa minningar“, bls. 26-27. Til gamans má geta að Auður Jónsdóttir hefur greint frá pví að með skrifum á bókinni Ósjálfrátt hafi hún óvart plantað fölskum minningum hjá frænku sinni og æskuvinkonu. Í bókinni er greint frá pví að persónur sem byggja á frænku Auðar og æskuvinkonu prífa saman íbúð. Eftir að bókin kom út hittust fyrirmyndirnar og rifjuðu upp fyrri kynni en staðreyndin er sú að pær höfðu aldrei áður hist og pví aldrei prifið saman íbúð en báðar voru sannfærðar um að pær hefðu gert pað eftir að hafa lesið bók Auðar. Auður Jónsdóttir, „Auður Jónsdóttir. Um heilann, opinn fræðslufundur um heilann í blíðu og stríðu“, https://vimeo.com/148931471.

Tekið skal fram að rannsóknir Loftus hafa verið gagnrýndar en sumir telja að pað sé ekki eins auðvelt að skapa falskar minningar hjá fólki eins og hún og samstarfsmenn hennar hafa haldið fram. Sjá til dæmis Chris R. Brewin, Bernice Andrews og Laura Mickes, „Regaining Consensus on the Reliability of Memory“, Current Directions in Psychological Science 29: 2/2020, bls. 121-125, hér bls. 121-124. Styr hefur líka staðið um bældar minningar úr æsku sem fólki hefur tekist að rifja upp síðar meir. Sumir telja að slíkar minningar geti verið falskar á meðan aðrir líta svo á að reynslan af tráma sé ástæðan fyrir minnisleysinu. Eins og fyrr var nefnt er pað persónubundið hvernig fólk man fortíðina par með talin áföll. Pótt flestir muni trámatíska atburði gjarnan fremur vel má vera að sumum reynist mun erfiðara að nálgast minningar um slíka reynslu og í sumum tilvikum getur verið að bældu minningarnar séu tilbúningur, annað hvort hafi einhver plantað peim í koll einstaklingsins eða hann hafi skapað pær sjálfur með hjálp ímyndunaraflsins. Samanber Gail S. Goodman, Lauren Gonzalves og Samara Wolpe, „False Memories and True Memories of Childhood Trauma. Balancing the Risks", Current Directions in Psychological Science 7: 1/2019, bls. 29-31, hér bls. 29-30 og Árni Kristjánsson, „Að skapa minningar“, bls. 26-33. 
Barn kryddar allt með ímyndun sinni, ég veit pað, ég á sjálf tvö börn [...]. En ég heyri ennpá brakið í beininu, ég heyri hana snökta: Ekki Bjarni! og mér finnst ég heyra hann bora sér stynjandi inn í hana, pó að ég óski pess heitast af öllu að hljóðin séu bara hryllingur sem hræðslan bjó til, af pví ég sá einhvern tímann bíómynd par sem konu var nauðgað og hljóðin voru pau sömu, kannski sá ég hana löngu seinna og finnst bara að hljóðin í minningunni hafi verið svipuð pó að pau hafi ekki verið pað. Og kannski eru pau ímyndun mín, Saga, kannski! (197)

Minnisrannsóknir sem gerðar hafa verið á fölskum minningum hafa leitt í ljós að ef einstaklingur ímyndar sér atburð og reynir að sjá myndir fyrir hugskotssjónum sínum er líklegra en ella að hann komi til með að trúa pví að atburðurinn hafi átt sér stað. ${ }^{82}$ Lýsingar Jóhönnu bera með sér að minningar fortíðarinnar ásæki hana; hún heyrir enn hljóðin sem tengjast peim. Efinn sem einkennir bó allt mál hennar vitnar um að hún vonar að ímyndunaraflið hafi hlaupið með hana í gönur, pað sem hún telur sig muna hafi aldrei gerst. Engu að síður óttast hún að afstaða hennar til föður síns eftir að hann hætti að drekka og lét af barsmíðunum hafi haft pau áhrif að hún reyni að afneita kynferðislega ofbeldinu og telja sér trú um að pað sé hennar eigin hugarburður. ${ }^{83}$ Óvissan um minningar fortíðarinnar er pví ekki síst rót sársaukans sem hún finnur fyrir.

Varnaglarnir sem Jóhanna slær gera pað að verkum að Saga á erfitt með að trúa ásökunum hennar á hendur föður peirra. Hún veltir fyrir sér hvort móðursystir peirra heitin, Elínborg, hafi haft áhrif á minni systurdóttur sinnar. Elínborg var einhleyp og barnlaus en hún átti í flóknu sambandi við Kristínu systur sína einkum vegna pess að henni var í nöp við mág sinn. Elínborg taldi að mágur hennar ætti sök á dauða Katrínar en hún var eina manneskjan sem var reiðubúin að margræða ofbeldið við Jóhönnu. Рað er pví hugsanlegt að skoðanir Elínborgar hafi litað orðræðu hennar og hún plantað fölskum minningum hjá frænku sinni. Jóhanna viðurkennir enda að hún viti ekki fyrir víst hvað séu minningar hennar og hverjar séu úr hugskoti Elínborgar: „Ég hafði sagt Elínborgu allt sem ég vissi og hún endursagði pað og skreytti pangað til pað hætti að vera minningin mín og varð minningin hennar. Ég á aldrei eftir að vita hvað ég hef lifað og hvað er úr huga Elínborgar“"(203).

82 Elizabeth F. Loftus, „The reality of repressed memories“, American Psychologist 48: 5/1993, bls. 518-537, hér bls. 533 .

83 Auður Jónsdóttir, Stóri skjálfti, bls. 197. 
Með pví að tefla saman pessum tveimur persónum, Sögu og Jóhönnu, er vel dregið fram á hve ólíkan hátt fólk getur minnst sömu atvika og fjölskyldumeðlima, um leið og sýnt er fram á að minnið getur leikið alla grátt hvort sem peir eru veikir, eins og Saga, eða heilbrigðir, eins og Jóhanna. Persónurnar mynda jafnt andstæður og hliðstæður, önnur man fortíðina of vel og man jafnvel pað sem aldrei gerðist á meðan hin man lengi vel ekki neitt. Báðar eiga pær pað sameiginlegt að lifa í óvissu pví pær geta ekki hent reiður á fortíðinni og vitað nákvæmlega hvað gerðist. Auk pess geta pær ekki skorið úr um hvar skilin liggja á milli trámaminninga og peirra sem hugsanlega eru falskar. Óvissan kann að rugla lesanda í ríminu sem veit líklega ekki hverju hann á að trúa en um leið getur hún aukið skilning hans á pví hve mikið ólíkindatól minnið er og hversu mikinn vafa pað felur í sér.

Рað er að vísu aukaatriði hvað gerðist nákvæmlega í fortíð systranna pví mestu máli skiptir að pær hafa rætt saman um tráma fortíðarinnar. Samtalið gegnir veigamiklu hlutverki í bataferli peirra beggja pví pótt Saga sé sú hin veika pá er pað Jóhönnu einnig mikilvægt að fá tækifæri til að tjá sig um áfallið og deila ótta sínum með öðrum. Saga veit að hún kemur aldrei til með að muna allt úr fortíðinni en hún man sársaukann. Með pví að viðurkenna dauða Katrínar fyrir sjálfri sér og ræða um hann, tildrög hans og eftirköst verður trámað hluti af sjálfsævisögulegu minni hennar. Par með getur hún betur skilið tilfinningarnar sem tengjast áfallinu og áhrif peirra. Раð er algengt að eftirlifendur tráma finni fyrir sektarkennd og ótta. ${ }^{84}$ Eftir samtalið við Jóhönnu rennur upp fyrir Sögu að hún hefur alla tíð kennt sjálfri sér um dauðdaga Katrínar vegna pess að hún gat ekki bjargað henni. Sektarkenndin hefur haft áhrif á sambandið við Berg pví vegna hennar hefur Saga óttast að sagan komi til með að endurtaka sig, annað barn í hennar umsjá muni láta lífið sinni hún pví ekki fullkomlega. Fyrir vikið hefur hún ofverndað Ívar og engum treyst fyrir honum nema sjálfri sér. Ranghugmyndir Sögu um fortíðina og hræðsla í nútíðinni kallast á við fyrrnefnd skrif Dori Laub um hvaða áhrif pað getur haft ef einstaklingur tekst ekki á við tráma fortíðarinnar og ræðir pað ekki við aðra.

Flogaköstin í upphafi bókar kippa fótunum undan Sögu. Pau neyða hana til sjálfsskoðunar sem verður til pess að hún tekst loksins á við trámu fortíðarinnar og sleppir tökum á afneituninni og pögguninni sem hefur einkennt allt hennar líf frá pví að Katrín dó. Jákvæðu áhrifin láta ekki á sér standa. Saga parf ekki lengur að lifa í tveimur aðskildum heimum - heimi

${ }^{84}$ Aphrodite Matsakis, „Trauma and It's Impact on Families“, bls. 21. 
trámans og heimi nútímans - pví með pví að viðurkenna áfallið sameinar hún heimana; trámað verður hluti af lífssögu hennar. Par með parf hún ekki lengur að eyða ómældri orku í að afneita sársauka fortíðarinnar, óttanum og sektarkenndinni heldur getur hún sampykkt kenndirnar og verið meðvituð um pær án pess pó að pær stjórni lífi hennar og líðan. Í lok sögu hefur Saga öðlast frásagnarminni um fyrri áföll og er reiðubúin til að deila reynslunni með Bergi, segja honum frá Katrínu og útskýra hvers vegna hún hefur vantreyst honum fyrir syni peirra. Sjálfsskoðunin hefur gert hana meðvitaða um eigin mistök í uppeldi Ívars en með pví að viðurkenna pau er ljóst að afneitunin litar ekki lengur líf hennar, hún hefur gert upp við fortíðina og er tilbúin að einbeita sér að nútíðinni. Saga kemst að peirri niðurstöðu að hún vill rækta ástina og eyða lífinu með Bergi. Veikindin og sjálfsskoðunin í kjölfarið hafa kennt henni að hún stendur ekki ein, hún parf ekki alltaf að vera við stjórnartaumana og afneita erfiðleikum fortíðarinnar heldur getur hún slakað á og treyst öðrum. Рað er pví einkar írónískt að Saga er of sein, Bergur er kominn í nýtt samband en pað er ópægileg staðreynd sem hún hefur gleymt - eða kosið að gleyma.

\section{Að lokum}

Í leitinni að sjálfri sér finnur Saga möppu á tölvunni sinni sem heitir Markmið. Mappan er að vísu tóm að undanskilinni einni setningu: „Hvorki stjórna né vera stjórnað““ (180). Í lok bókar virðist markmiðinu vera náð pví með ítarlegri sjálfsskoðun hefur Saga komist á pann stað að hún getur sleppt tökunum og treyst öðrum. Рað er rækilega undirstrikað í lokakaflanum en pá er sem Saga stari sig í störuflog ${ }^{85}$ svo hún fjarar smátt og smátt út úr veruleikanum og sjálfri sér. Ólíkt krampafloginu í upphafi bókar sem skapaði óvissu og vanlíðan eykur störuflogið sátt og vellíðan. ${ }^{86}$ Veruleikinn verður draumkenndur pegar Saga lýsir pví hvernig hún verður sífellt léttari og fjarlægari bæði líkama sínum og aðstæðum. Störuflogið hefur pau áhrif að

85 Störuflog eru flog sem „vara stutt, oft nokkrar sekúndur. Viðkomandi missir meðvitund án pess að detta. Starir fram fyrir sig, sjáöldur víkka. Síðan kemst hann til meðvitundar á ný og tekur pá gjarnan upp fyrri iðju eins og ekkert hafi í skorist." „Spurningar og svör“, Lauf, sótt 4. júlí 2020 af http://www.lauf.is/ spurningar-and-svor/.

86 Auður Jónsdóttir hefur greint frá pví að sem barn hafi hún stundum starað sig í störuflog pví henni pótti tilfinningin svo góð, að fjara út. Samkvæmt henni búa fleiri yfir slíkri reynslu. Auður Jónsdóttir, „Auður Jónsdóttir. Um heilann, opinn fræðslufundur um heilann í blíðu og stríðu“, https://vimeo.com/148931471. 
henni verður eigið pýðingarleysi ljóst: „hún er stjórnlaus líkami í stjórnlausum heimi, móðir án barns, gift kona án eiginmanns, húseigandi sem á hvergi heima“ (297). Tilfinningarnar sem vakna eru ekki lengur ótti, sektarkennd eða eftirsjá heldur fyrst og fremst skilyrðislaus ást og samkennd til Ívars og Jóhönnu. ${ }^{87}$ Í lok bókar er ekki ljóst hvað verður um Sögu, deyr hún eða lifir áfram? Svarið liggur hjá lesanda sem parf að gera upp við sig hvernig hann fyllir inn í pá eyðu; ${ }^{88}$ pangað til er Saga „hugarburður í frjálsu falli“. ${ }^{89}$

Stóri skjálfti er athyglisverð stúdía á manninum og óáreiðanleika minnisins. Pótt flogaveik persóna sé í brennidepli og upplifun hennar markist af afleiðingum sjúkdómsins gera tengsl veikindanna við minnið, gleymskuna og áföllin pað að verkum að reynsla Sögu er sammannleg. Sagan eflir pví ekki aðeins skilning og pekkingu á flogaveiki og fylgikvillum hennar heldur varpar hún fyrst og fremst fram mikilvægum spurningum um hvernig við skiljum veruleikann: Munum við pað sem við munum? Vitum við pað sem við vitum? Hvaða sögur segjum við okkur pegar við endursköpum fortíðina? Eins og sýnt hefur verið fram á í pessari grein er pað manninum eiginlegt að skálda lífið svo pegar allt kemur til alls er kannski „allt okkar líf [...] ekkert nema skáldsaga“ (229).90

87 Líðanin sem Saga lýsir undir lokar bókar og ekki síst jákvæðu tilfinningarnar sem vakna hjá henni minna á áhrif hugleiðslu-aðferða sem eru stundaðar gagngert til að auka samkennd einstaklings með öðrum. Boris Borneman og Tania Singer, „The ReSource Training Protocol“, Compassion. Bridging Practice and Science, ritstjórar Tania Singer og Matthias Bolz, Munich: Max Planck, 2013, bls. 452-465, hér bls. 459. Auður Jónsdóttir hefur greint frá pví opinberlega að hugleiðsluæfingar sem hún hafi stundað hafi haft svipuð áhrif á hana og störuflog sem hún fékk sem barn svo pessi tengsl eru ekki úr lausu lofti gripin. Auður Jónsdóttir, „Auður Jónsdóttir. Um heilann, opinn fræðslufundur um heilann í blíðu og stríðu“, https://vimeo. com/148931471.

88 Auður Aðalsteinsdóttir hefur sagt að hið fullkomna stjórnleysi sem Saga finnur fyrir í lok sögu virðist eiga að tákna dauða. Sjá „Hvorki stjórna né vera stjórnað“, bls. 94. Tekið skal fram að Auður Jónsdóttir hefur bent á að vísindamenn hafa dregið fram líkindi með áhrifum störuflogs og eftirdauðareynslu. Auður Jónsdóttir, „Auður Jónsdóttir. Um heilann, opinn fræðslufundur um heilann í blíðu og stríðu“, https:// vimeo.com/148931471. Samber orð Auðar Jónsdóttur sem vísað var til í upphafi greinar.

90 Pessi grein er hluti af verkefninu Ímyndunaraflið (201196-0011) sem stutt er af Starfslaunasjóði sjálfstætt starfandi fræðimanna. Ég pakka ónefndum ritrýnum og Sigrúnu Margréti Guðmundsdóttur kærlega fyrir góðar og gagnlegar ábendingar við skrif greinarinnar. 


\section{ÚT D RÁTTUR}

Í skáldsögunni Stóra skjálfta eftir Auði Jónsdóttur er sagt frá persónunni Sögu sem á við minnisvanda að stríða í kjölfar flogakasta. Í pessari grein er fjallað um upplifun og reynslu persónunnar með tilliti til veikinda hennar. Rætt er um flogaveiki og hvaða líkingar eru hafðar um sjúkdóminn í sögunni. Pá er sjónum ekki síst beint að óáreiðanleika minnisins og hvernig fólk er sífellt að skálda lífið. Meðal annars er skoðað hvaða aðferðum Saga og aðrar persónur Stóra skjálfta beita til að rifja upp fortíðina og hvernig pær geta minnst sama atburðar á ólíkan máta. Sérstakur gaumur er gefinn að tengslum minnis og tráma en með dæmum úr bók Auðar er dregið fram hvernig minningar um erfiða reynslu eru gjarnan ólíkar öðrum minningum.

Lykilorð: Læknahugvísindi - minni - tráma - líkingar - Auður Jónsdóttir - Stóri skjálfti

\section{A B S T R A C T \\ „The memory is a strainer" \\ On Memory and Trauma in Grand Mal by Auður Jónsdóttir}

The novel Stóri skjalfti (Grand Mal) by Auður Jónsdóttir tells the story of Saga, who struggles with memory problems following epileptic seizures. This article discusses the character's experience in light of the illness. Both epilepsy and the metaphors used for the illness in the novel are addressed. A special focus is put on the unreliability of memory and how people are constantly reinventing their lives. Additionally, the article examines the methods used by Saga and other characters in Grand Mal to recall the past, and how their recollection of certain events can vary individually. The connection between memory and trauma is highlighted. Examples from Jónsdóttir's book show how memories of difficult experiences often differ from other memories.

Keywords: Medical Humanities - Memory - Trauma - Conceptual Metaphors Auður Jónsdóttir - Grand Mal

\section{GuĐrún Steindórsdóttir}

Doktor í íslenskum bókmenntum

gus26@hi.is 
